\title{
The DNA-dependent protein kinase
}

\author{
Graeme C.M. Smith and Stephen P. Jackson ${ }^{1}$
}

Wellcome/Cancer Research Campaign Institute, Cambridge, CB2 1QR, UK; Department of Zoology, University of Cambridge, Cambridge, CB2 3EJ, UK

The DNA-dependent protein kinase (DNA-PK) is a nuclear serine/threonine protein kinase that is activated upon association with DNA. Biochemical and genetic data have revealed DNA-PK to be composed of a large catalytic subunit, termed DNA-PKcs, and a regulatory factor termed $\mathrm{Ku}$. In recent years, mammalian DNA-PK has been shown to be a crucial component of both the DNA double-strand break (DSB) repair machinery and the $V(D) J$ recombination apparatus. In addition, recent work has implicated DNA-PK components in a variety of other processes, including the modulation of chromatin structure and telomere maintenance.

Our DNA is constantly under attack from reactive oxygen intermediates-by-products of the oxidative metabolism we have evolved for energy supply. Reactive oxygen species are capable of producing DNA singlestrand breaks and, where two of these are generated in close proximity, DNA double-strand breaks (DSBs). In addition, single- and double-strand breaks can be induced when a DNA replication fork encounters a damaged template, and are generated by exogenous agents such as ionizing radiation (IR) and certain anti-cancer drugs (e.g., bleomycin). DSBs also occur as intermediates in site-specific $V(D) J$ recombination, a process that is critical for the generation of a functional vertebrate immune system. If DNA DSBs are left unrepaired or are repaired inaccurately, mutations and/or chromosomal aberrations are induced, which in turn may lead to cell death or, in extreme cases, cancer. To combat the serious threats posed by DNA DSBs, eukaryotic cells have evolved several mechanisms to mediate their repair. In higher eukaryotes, the predominant of these mechanisms is DNA nonhomologous end-joining (NHEJ), also known as illegitimate recombination. DNA-PK plays a key role in this pathway.

Early studies on DNA-PK focused primarily on its biochemistry, and led researchers to speculate on its function as a modulator of transcription. However, this viewpoint took a dramatic change when it was shown that DNA-PK is activated most potently by DNA DSBs, suggesting that it might play a role in recognizing DNA damage. This observation stimulated investigations into the potential role of DNA-PK in DNA repair and led to

${ }^{1}$ Correspoding author.

E-MAIL spj13@mole.bio.cam.ac.uk; FAX 44-1223 334089. the identification of cell lines that are radiosensitive due to mutations in DNA-PK components. At around the same time, DNA-PKcs was found to be mutated in cells derived from the radiosensitive and $V(D) /$ recombination deficient severe combined immune-deficient (SCID) mouse. The subsequent cloning of the DNA-PKcs cDNA revealed this very large polypeptide to be similar in sequence, over its kinase domain, to an expanding family of proteins involved in controlling cell cycle progression and maintaining genomic stability. Here, we review what is currently known about DNA-PK, with emphasis on recent biochemical analyses that have begun to shed light into how DNA-PK and associated proteins function at the molecular level. We also focus on the results of ablating the function of DNA-PK subunits in both yeast and mice, which have suggested other physiological roles for DNA-PK and its components.

\section{DNA-PK: a historical perspective}

A conspicuous property of DNA-PK is that its catalytic activity is triggered upon association with DNA. The ability of double-stranded DNA (dsDNA) to stimulate a protein kinase was first observed in mouse spleen cell nuclear extracts by Ohtsuki et al. (1980), although whether this activity corresponded to DNA-PK is uncertain. Later, a DNA-activated protein kinase was discovered serendipitously by Walker et al. (1985) when studying RNA activation of protein phosphorylation-an RNA sample contaminated with DNA led to the finding that rabbit reticulocyte, human cell, Xenopus oocyte, and several murine and amphibian cell extracts are capable of phosphorylating endogenous proteins in a dsDNA-dependent manner. Independently, a DNA-dependent kinase was discovered in HeLa cell extracts as an activity that was capable of phosphorylating SV40 virus large $\mathrm{T}$ antigen, transcription factor $\mathrm{Sp} 1$, and a variety of other DNA-binding proteins (Carter et al. 1988; Jackson et al. 1990). Intriguingly, these two latter studies noted that the enzyme functions efficiently in the presence of linear but not supercoiled DNA. Through exchange of materials, the three groups concluded that they had identified the same kinase, henceforth termed DNA-PK (Carter et al. 1990; Jackson et al. 1990; LeesMiller et al. 1990). Initial work indicated that DNA-PK activity copurified with a $\sim 350-\mathrm{kD}$ polypeptide, originally termed 'p350'. Lees-Miller et al. (1990) did note, 
however, that this protein did not always copurify precisely with DNA-PK catalytic activity and found that a high resolution chromatographic step resulted in a p350 preparation dramatically reduced in catalytic activity. This suggested either that p350 did not correspond to DNA-PK or that p350 required an additional polypeptide(s) to function. The latter possibility was shown to be correct through subsequent biochemical studies, which revealed that DNA-PK comprises a large catalytic subunit (p350; now termed DNA-PKcs) and a DNA-targeting component corresponding to the nonspecific DNA end-binding protein $\mathrm{Ku}$ (Dvir et al. 1992; Gottlieb and Jackson 1993).

\section{DNA-PKes is a member of the PI 3-kinase family}

Cloning of the DNA-PKcs cDNA revealed that it corresponds to a $\sim 470-\mathrm{kD}$ polypeptide, the amino-terminal 3500 amino acid residues of which does not appear to have significant homology to other characterized proteins (Hartley et al. 1995). More significantly, however, the carboxy-terminal 500 residues of DNA-PKcs comprises a catalytic domain that falls into the phosphatidylinositol 3 (PI 3)-kinase family (Hartley et al. 1995; Poltoratsky et al. 1995). Although this suggested initially that DNA-PK might be capable of phosphorylating inositol phospholipids, like certain well-characterized members of the PI 3-kinase family (Toker and Cantley 1997), the available evidence indicates that DNA-PK has protein but not lipid kinase activity (Hartley et al. 1995; Smith et al. 1999). At a similar time to the cloning of the DNA-PKcs cDNA, the genes and cDNAs for a range of other large PI 3-kinase-like (PIKL) proteins were identified and cloned (for reviews, see Zakian 1995; Jackson 1996). These proteins have been shown to be involved in controlling transcription, the cell cycle and/or genome stability in organisms ranging from yeast to man. DNAPKcs, however, appears to be restricted to higher eukaryotes; clear homologs have been identified in mouse (Araki et al. 1997), horse (Shin et al. 1997), and Xenopus laevis (Labhart 1997), but is not present in the genome of Saccharomyces cerevisiae and has not been identified in the genomic sequences available for Caenorhabditis elegans.

Besides DNA-PKcs, probably the best characterized member of the PIKL family is ATM, the protein deficient in the human neurodegenerative and cancer predisposition condition ataxia-telangiectasia $(\mathrm{A}-\mathrm{T}$; for review see Lavin and Shiloh 1997). ATM has been linked intimately to the detection and signaling of DNA damage (for review, see Rotman and Shiloh 1998). ATM homologs also exist in S. cerevisiae (Tellp; Greenwell et al. 1995; Morrow et al. 1995) and Schizosaccharomyces pombe (Naito, et al. 1998) and are involved in genome surveillance and in controlling telomeric function. Another PIKL protein involved in genome surveillance is human AT-related (ATR)/FRAP-related (FRP) (Cimprich et al. 1996), together with its homologs in S. cerevisiae (Meclp; Kato and Ogawa 1994; Weinert et al. 1994), S. pombe (Rad3; Jimenez et al. 1992; Seaton et al. 1992), and Drosophila (mei-41; Hari et al. 1995). Human FRAP (Kunz et al. 1993; Brown et al. 1994; Chiu et al. 1994; Sabatini et al. 1994) and its S. cerevisiae homologs Torlp and Tor $2 p$ (Heitman et al. 1991; Helliwell et al. 1994), are also in the PIKL family. These proteins control mRNA translation in response to nutrient supply and certain other environmental stimuli, including polypeptide growth factors (Brunn et al. 1997). As with DNA-PKcs, the available data support the proposal that the above PIKL family members are serine/threonine protein kinases but not lipid kinases. A final, apparently more distantly related, member of the PIKL family has been identified recently, and has been named Tralp in $S$. cerevisiae and TRRAP in humans (McMahon et al. 1998; Saleh et al. 1998). This $\sim 450 \mathrm{kD}$ polypeptide is associated with the SAGA histone acetyltransferase complex that functions in transcriptional control (Apone et al. 1998; Grant et al. 1998; Natarajan et al. 1998). Intriguingly, TRRAP/Tralp (and its homolog in C. elegans) appears to have lost its ability to function as a kinase and most probably acts as a scaffold for proteins involved in chromatin remodeling.

Outside the kinase domain, DNA-PKcs has little or no similarity with other proteins and, besides the presence of a putative leucine zipper motif, which is required for interactions with the high-affinity DNA binding protein C1D (Yavuzer et al. 1998), it has no clear features that might hint at its molecular functions. Nevertheless, the carboxy-terminal quarter of DNA-PKcs has been reported to interact with $\mathrm{Ku}$ (Jin et al. 1997). Last year, a significant step forward in understanding the architecture of DNA-PKcs was brought about by cryoelectron microscopy imaging of DNA-PKcs to a resolution of $\sim 20$ $\AA$ (Chiu et al. 1998). This suggested that DNA-PKcs has an open, pseudo two-fold symmetric structure with a gap separating a crown-shaped top from a rounded bottom. The hollow nature of the DNA-PKcs interior suggests it may interact with DNA via internalization of doublestranded ends through tunnels and cavities identified in the structure. Although the size of the interior of the protein is large, it is thought not big enough to simultaneously internalize the $\mathrm{Ku}$ heterodimer and DNA. Therefore, the Ku binding site(s) is most probably located on an exterior surface. Another more recent study has reported the structure of DNA-PKcs at $22 \AA$ resolution by electron crystallography (Leuther et al. 1999). This structure shows DNA-PKcs to be similar to other dsDNA-binding proteins, with it possessing an open channel and an enclosed cavity with three openings large enough to accommodate ssDNA. Biochemical analyses based on this knowledge have suggested that activation of the kinase requires interactions with both double- and single-stranded DNA (Leuther et al. 1999). It will be of great interest to conduct more detailed structural determinations of DNA-PKcs and the DNA-PKcs/Ku complex to learn more about their molecular architectures.

\section{Analyses of the $\mathrm{Ku}$ subunits}

$\mathrm{Ku}$ was first identified as an autoimmune antigen in patients with scleroderma-polymyositis overlap syndrome 
(Mimori et al. 1981). The initial and detailed characterization of this protein revealed it to be a highly abundant nonspecific DNA-binding protein comprising two tightly-associated subunits of $\sim 70$ and $83 \mathrm{kD}$ (Ku70 and $\mathrm{Ku} 80$, respectively; Ku80 is sometimes referred to as $\mathrm{Ku} 86$ ). The cloning of cDNAs and genes for Ku subunits from a variety of species has now taken place and has revealed that both $\mathrm{Ku} 70$ and $\mathrm{Ku} 80$ exist in organisms ranging from yeast to man (for review, see Dynan and Yoo 1998). Although sequence analyses have so far told us relatively little about the structural organization of the $\mathrm{Ku}$ heterodimer, it has recently become apparent that homology exists between Ku70 and Ku80, suggesting that they arose through the duplication and subsequent divergence of a single polypeptide, which presumably functioned as a homodimer (Dynan and Yoo 1998; D. Gell and S.P. Jackson, unpubl.). Each Ku subunit has been reported to possess a leucine-zipper motif, but whether or not these have roles in the overall function or conformation of the proteins is still open to question (Wu and Lieber 1996). Also identified in the sequences of both Ku70 and Ku80 are weak ATP binding site homologies, which may be essential for the proposed ATPase and helicase functions of $\mathrm{Ku}$ (Cao et al. 1994; Tuteja et al. 1994; see below). However, the significance of the ATP-binding motifs is unclear, as mutation of these so far have not been found to affect Ku function in vivo (Jin and Weaver 1997; Singleton et al. 1997). Numerous yeast two-hybrid and biochemical studies have been conducted to map the regions of the Ku subunits that make contact with one another and with DNA (Wu and Lieber 1996; Jin and Weaver 1997; Osipovich et al. 1997; Cary et al. 1998; Wang et al. 1998). Although both conflicting and corroborating results have arisen from these studies, it seems apparent that a carboxy-terminal region of $\sim 150$ amino acid residues in both $\mathrm{Ku} 70$ and $\mathrm{Ku} 80$ are essential for dimerization, and that larger regions of both proteins are required for effective interactions with DNA ends. Still to be identified, however, are the precise residues that mediate the extremely strong Ku70-Ku80 interaction, interactions with DNA, and the weaker but critically important interaction with DNA-PKcs.

\section{DNA-binding properties of Ku}

The Ku heterodimer was first described as having the apparently unique ability to bind with high selectivity to free dsDNA ends (Mimori and Hardin 1986). The early studies on DNA binding by $\mathrm{Ku}$ revealed that it takes place with high affinity and that end binding is independent of the structure or sequence of the end (Mimori and Hardin 1986; Paillard and Strauss 1991; Falzon et al. 1993). Studies have also shown that $\mathrm{Ku}$ can bind to a variety of DNA structures; however, it does not bind to closed circular DNA (Dynan and Yoo 1998). Both Ku70 and Ku80 make contact with DNA, although it appears that Ku70 makes the more intimate interactions, with a carboxy-terminal stretch of 73-amino acid residues in Ku70 having been shown to make contact with DNA by Southwestern blot analysis (see Dynan and Woo 1998).
Importantly, and consistent with genetic data indicating that $\mathrm{Ku} 70$ and $\mathrm{Ku} 80$ are functionally dependent on each other (see later section), neither subunit alone can bind DNA effectively (Griffith et al. 1992; Ono et al. 1994; Wu and Lieber 1996; Ochem et al. 1997). Ku has been reported on many occassions to bind DNA in a sequencespecific manner. It now appears that in most cases this was artifactual and resulted from the high abundance of $\mathrm{Ku}$ and its unique DNA end-binding properties (see Dynan and Woo 1998 for an illuminating summary of this subject). Nevertheless, at least for the case of Ku binding to the NRE-1 element in the long terminal repeat of the mouse mammary tumor virus, it appears that this example of sequence specific binding by $\mathrm{Ku}$ does have some functional basis (Giffin et al. 1996).

In addition to being able to interact specifically with DNA ends, $\mathrm{Ku}$ also has the ability to translocate along DNA molecules in an ATP-independent manner (DeVries et al. 1989; Paillard and Strauss 1991). This and related properties have led to models in which the binding of Ku to DNA is likened to the sliding of a bead on a piece of string-DNA ends are not required for binding per se but are required for $\mathrm{Ku}$ to bind to or dissociate from the DNA template. Consistent with such a model, $\mathrm{Ku}$ can generate footprints at internal sites as well as the termini of linear DNA molecules (Mimori and Hardin 1986; DeVries et al. 1989). In addition, atomic force microscopy studies have revealed the existence of internal as well as DNA end-bound DNA-PK complexes, and have shown that Ku can juxtapose two DNA ends via a DNA looping mechanism (Cary et al. 1997). Finally in this regard, electrophoretic mobility shift assays have been employed to show that Ku can actually transit directly from one linear DNA molecule to another if the termini of the two DNAs are capable of base pairing (Bliss and Lane 1997). That the above DNA end-alignment activities may be of functional significance is suggested by the fact that Ku can stimulate DNA end ligation by eukaryotic DNA ligases in vitro (Ramsden and Gellert 1998).

Other, possibly interrelated functions that have been reported for Ku are helicase and ATPase activities. Tuteja et al. (1994) have shown that Ku preparations possess weakly processive helicase function. Furthermore, it has been reported that the $\mathrm{Ku} 70$ subunit contains the ATPase activity and is able to perform helicase function independently of Ku80 (Ochem et al. 1997). Cao et al. (1994) have also reported that $\mathrm{Ku}$ possesses weak (as compared to other known enzymes) but significant ATPase function and have shown that this is stimulated by DNA-PK-mediated phosphorylation. Perhaps relevant to the above, Ku70 and Ku80 do have some homology with classical Walker box ATP-binding motifs, although, as noted previously, mutation of these sites has not been found to impair Ku function in vivo.

\section{Mechanism of DNA-PK activation}

The original papers establishing $\mathrm{Ku}$ as a DNA-PK component revealed that it dramatically stimulates DNA- 
PKcs kinase function towards a variety of DNA-bound targets (Dvir et al. 1992, 1993; Gottlieb and Jackson 1993). The DNA-PKcs/Ku complex has been shown to phosphorylate proteins most effectively when it is bound to the same DNA molecule as DNA-PK itself, indicating that part of the activation produced by DNA is through the juxtaposition of DNA-PK and its target (Gottlieb and Jackson 1993). However, DNA also stimulates the ability of DNA-PK to phosphorylate non-DNA-binding peptide substrates, implying that binding to DNA must directly or indirectly induce an activating conformational change in DNA-PKcs. Recent studies with ATP noncompetitive inhibitors of DNA-PK indicate that such a conformational change is unlikely to correspond to an unmasking of the ATP-binding site (Izzard et al. 1999). Protein-DNA cross-linking studies have revealed that DNA-PKcs makes intimate contacts with the DNA, suggesting that DNA might directly induce conformational alterations (Lees-Miller et al. 1990; Gottlieb and Jackson 1993). Consistent with this idea, DNA-PKcs activity can be stimulated to some degree in vitro by DNA in the absence of $\mathrm{Ku}$ (Yaneva et al. 1997; Hammarsten and Chu 1998; West et al. 1998). Taken together with data revealing that $\mathrm{Ku}$ helps to target DNA-PKcs to DNA (Dvir et al. 1992; Gottlieb and Jackson 1993; Suwa et al. 1994; Chan et al. 1996; Cary et al. 1997; Yaneva et al. 1997; Hammarsten and Chu 1998; West et al. 1998), the available data lead to a model in which $\mathrm{Ku}$ recruits DNA-PKcs to DNA, which in turn facilitates DNAPKcs-DNA interactions that release the catalytic potential of the DNA-PK complex. Such a model is also consistent with physiological data revealing that $\mathrm{Ku}$ and DNA-PKcs function, at least in a large part, as an interdependent two-component system (see below). Clearly, many questions regarding the mechanism of DNA-PK activation remain to be answered, including how DNAPKcs and $\mathrm{Ku}$ bind to one another and to DNA, and perhaps most importantly, how only very specific types of DNA structure mediate DNA-PK activation.

\section{Regulation of DNA-PK}

As well as DNA-PK being modulated through its interactions with $\mathrm{Ku}$ and DNA, it has become apparent that DNA-PK activity and function are likely to also be regulated by a variety of other mechanisms. One area that has received particular attention has been the ability of other proteins to influence the activity of DNA-PKcs and/or the DNA-PKcs/Ku complex. For example, the high-affinity DNA binding protein C1D was identified through the yeast two-hybrid approach as interacting with the putative leucine zipper region of DNA-PKcs (Yavuzer et al. 1998). Notably, DNA-bound C1D can trigger DNA-PK activation in a DNA end-independent manner, possibly via inducing alterations in the structure of the DNA double helix. Although the physiological function for C1D is not yet clear, the observations that it behaves as a component of the nuclear matrix and is induced in response to IR suggests that it could play a role in targeting DNA-PK to specific nuclear regions in response to genotoxic insult. Such a model would be consistent with reports that Ku80-deficient xrs5 cells are reported to have nuclear envelope and nuclear matrix alterations compared to their wild-type controls (Yasui et al. 1991; Korte and Yasui 1993). Perhaps related to the activation of DNA-PK by C1D, high mobility group (HMG) proteins 1 and 2 have also been shown to be capable of stimulating DNA-PK activation in vitro, hinting to the possibility that DNA-PK activation in vivo is influenced by chromatin context (Watanabe et al. 1994; Yumoto et al. 1998). Another protein-protein interaction implicated in regulating DNA-PK function is that between DNA-PKcs and the Lyn tyrosine kinase, which is capable of disrupting the DNA-PKcs/ Ku complex in vitro (Kumar et al. 1998). Heat shock transcription factor 1 (HSF1) can also stimulate DNA-PK activity in vitro through a mechanism that involves interactions between HSF1 and $\mathrm{Ku}$ and weaker interactions between HSF1 and DNA-PKcs (Peterson et al. 1995a; Huang et al. 1997). These findings suggest that HSF1 could cooperate with $\mathrm{Ku}$ and DNA-PKcs, possibly through stabilizing interactions between the DNA-PK holoenzyme and DNA. Although the physiological relevance of this interaction is currently unclear, it will certainly be of interest to determine whether DNA-PK-deficient animals or cells display hypersensitivity to heat or altered heat shock responses.

Another example of a protein-protein interaction modulating DNA-PK activity has been revealed through studies on the human Ku80 autoantigen-related protein (KARP-1; Myung et al. 1997, 1998). This protein, which apparently is only present in primates, is expressed from the Ku80 locus and corresponds to a 9-kD amino-terminally extended derivative of Ku80. The KARP-1-specific domain encodes heptad repeats of leucine residues flanked by a basic region, and expression of dominantnegative derivatives of KARP-1 in cells has been reported to result in a derepression of DNA-PK activity and hypersensitivity to IR. These observations, together with the observation that KARP-1 is induced upon irradiation of cells in a p53- and ATM-dependent manner (Myung et al. 1998), suggests that KARP-1 might be involved in latter stages of DNA DSB repair, or may be required to repair lesions that are refractory to the actions of the DNA-PK complex containing the constitutively-expressed form of $\mathrm{Ku}$.

Consistent with its proposed role as a primary DNA damage sensor and not as an inducible downstream effector of DNA damage signaling, DNA-PK is present at relatively high levels (up to $1 \%$ of HeLa cell nuclear protein) and its levels do not appear to be regulated strongly by DNA-damaging agents (Lee et al. 1997). However, rodents have much lower levels of DNA-PKcs, Ku, and DNA-PK activity than primate cells (Anderson and Lees-Miller 1992; Finnie et al. 1995). Indeed, it is notable that DNA-PK levels in a variety of species correlate well with the species' life-span, suggesting that elevated DNA-PK levels in longer-lived organisms is a mechanism to enhance genomic stability. Despite DNA-PK being constitutively present, its activity does appear to 
be modulated throughout the cell cycle (Lee et al. 1997). Furthermore, elevated levels or activity of Ku have been reported in response to cellular growth state (Cai et al. 1994) possibly reflecting the increased need for efficient DNA DSB repair in rapidly dividing cells. DNA-PK activity is found to be induced to some extent when lymphoid cells are induced to undergo site-specific $V(D) J$ recombination or switch recombination (Grawunder et al. 1996); two processes that rely on DNA-PK function (e.g., see Rolink et al. 1996; Casellas et al. 1998; Manis et al. 1998). However, as this result was obtained from cells in culture, it remains unclear if this activation of DNA-PK occurs in the whole animal. In addition, decreased vitamin D receptor expression has been found to reduce DNA-PKcs mRNA levels, although the reason for this is currently obscure (Dabrowski et al. 1998).

The recent cloning and analysis of the $5^{\prime}$-untranslated region of the DNA-PKcs gene has revealed it to have no TATA or CCAAT box sequences and to contain potential binding sites for the ubiquitous transcription factor Sp1-features associated with 'housekeeping genes' (Connelly et al. 1998). It will be of interest to study the potential transcriptional induction of DNA-PK components in response to the aforementioned stimuli. Another potential mode for DNA-PK regulation, suggested from the cloning of its CDNA, is at the level of premRNA splicing. The initial DNA-PKcs cDNA sequence lacked an exon of 93 base pairs that was found in subsequent studies (Hartley et al. 1995; Poltoratsky et al. 1995; Connelly et al. 1996). Although it is possible that this reflects aberrant rather than differential splicing in the initial clone, the fact that the differentially spliced exon encodes a part of the catalytic domain suggests that its differential usage could have an important regulatory function.

DNA-PK activity also appears to be regulated by posttranslational modification. For example, autophosphorylation of DNA-PKcs in vitro has been shown to induce its dissociation from $\mathrm{Ku}$ and result in inhibition of DNA-PK catalytic function (Chan and Lees-Miller 1996). Another DNA-PKcs-phosphorylation event that has been reported to dissociate the DNA-PKcs-Ku complex is that mediated by the c-Abl proto-oncogene product (Jin et al. 1997; Kharbanda et al. 1997). Because c-Abl is itself induced in response to IR in a manner that is reported to be DNA-PK dependent (Kharbanda et al. 1997), this suggests the existence of an autoregulatory negative feed-back loop that might lead to repression of DNA-PK activity after the appropriate DNA damage signaling and/or repair pathways have been initiated. Another post-translational modification that has been found recently to affect DNA-PK activity in vitro is ADP-ribosylation mediated by the DNA repair-associated enzyme poly-ADP(ribosyl) transferase (PARP), which can stimulate the ability of DNA-PK to phosphorylate some protein substrates (Ruscetti et al. 1998). Although the physiological relevance of this is currently unclear, the fact that PARP activity is also induced by DNA damage suggests that it may be a way of coordinating the activities of the DNA-PK and PARP systems.
Perhaps the most striking characterized examples of regulating DNA-PK activity are its inactivation during programmed cell death and upon viral infection. During apoptosis, DNA-PKcs is specifically cleaved by caspase-3 or a caspase-3-like protease with subsequent loss of its kinase potential (Casciolarosen et al. 1995; Han et al. 1996; LeRomancer et al. 1996; Song et al. 1996). This DNA-PK inactivation is probably to prevent signaling from or repair of the degraded genomic DNA that is produced during the latter steps of the apoptotic pathway. Furthermore, as apoptosis is an energy-dependent process, DNA-PK inactivation might prevent the massive activation of this highly abundant kinase by fragmented genomic DNA and the subsequent depletion of ATP reserves. Interestingly, although neither $\mathrm{Ku}$ subunit is a target for the apoptotic proteases, a loss of Ku protein has been observed in apoptotic lymphocytes and in myeloid cells destined to undergo apoptosis (Ajmani et al. 1995). A negative regulation of DNA-PK function by protein kinase $\mathrm{C} \delta$ in apoptotic cells has also been proposed (Bharti et al. 1998). In a different scenario, DNA-PKcs has been found to be degraded, apparently via a proteosomal mechanism, during herpes simplex virus (HSV) type 1 infection of mammalian cells (Lees-Miller et al. 1996; Parkinson et al. 1999). Although other possibilities exist, this suggests that inhibiting DNA-PK function aids virus replication and/or packaging. In line with this idea, at low titers, HSV has been reported to replicate more efficiently in a DNA-PKcs null cell line compared to the DNA-PK positive cells (Parkinson et al. 1999).

\section{Manipulation of DNA-PK activity by exogenous agents}

$\mathrm{Ku}$ has the ability to bind to artificially derived RNA molecules with an affinity as great as that observed for dsDNA (Yoo and Dynan 1998). Binding to these RNAs does not result in DNA-PK activation, meaning that they have the potential to be developed into agents that can regulate DNA-PK function in vitro or in vivo. The sequence similarity between DNA-PKcs and PI 3-kinases has also provided a route to identify DNA-PK inhibitors. Thus, Wortmannin, a classical PI 3-kinase inhibitor, was found to inhibit DNA-PK with an IC50 of $\sim 250 \mathrm{nM}$, around two orders of magnitude higher than is required for PI 3-kinase inhibition (Hartley et al. 1995). A more detailed analysis has shown that, similar to PI 3-kinases, DNA-PK is inhibited by Wortmannin in a noncompetitive manner, and that Wortmannin is able to bind covalently to the kinase active site (Izzard et al. 1999). Wortmannin is capable of binding to DNA-PKcs in vivo (Izzard et al. 1999) and has been shown to radiosensitize mammalian cells (Price and Youmell 1996; Boulton et al. 1996; Rosenzweig et al. 1997; Hosoi et al. 1998). Other PI 3-kinase inhibitors, such as LY294002, quercitin, quercitrin, and rutin, have also been shown to inhibit DNA-PK activity, with LY294002 being demonstrated to radiosensitize cells (Rosenzweig et al. 1997; Izzard et al. 1999). Another compound that has potential as a DNA-PK inhibitor is OK1035 (Take et al. 1995, 1996). Although somewhat nonspecific in nature, these 
compounds represent useful tools for elucidating the functions of DNA-PK in DNA repair and other processes, both in vivo (see above references) and in vitro (Gu et al. 1996, 1998; Baumann and West 1998). In addition, they might serve as starting points for the identification of more specific inhibitors of DNA-PK and/or the other related PI 3-kinases for academic research or for the development of pharmacologically active therapeutic agents.

\section{Role of DNA-PK and associated factors in DNA NHEJ}

The involvement of DNA-PK in DSB repair became evident from analyses involving a specific series of mutant rodent cell lines. Early studies into these cells found them to be hypersensitive to IR and radiomimetic agents with little or no cross sensitivity to other types of DNA damaging agent, and showed them to be defective in the repair of chromosomal DNA DSBs (for review, see Zdzienicka 1995). Subsequent cell fusion studies allowed these cells to be placed into three distinct complementation groups, termed IR4, IR5, and IR7, and the human genes complementing them were preassigned to the $X R C C$ nomenclature (X-ray cross-complementing; XRCC4 is the gene that complements cells of IR4, XRCC5 complements IR5, and XRCC7 complements IR7; Thompson and Jeggo 1995; Zdzienicka 1995).

In late 1994 and early 1995, a series of reports were published showing that cells of IR5 lack Ku DNA endbinding activity and can be complemented by the gene for Ku80 (Getts and Stamato 1994; Rathmell and Chu 1994; Smider et al. 1994; Taccioli et al. 1994; Boubnov et al. 1995; Finnie et al. 1995). Prompted by the above findings, several groups then established that cells of IR7 also lack DNA-PK activity; in this case the defect being complemented by the gene for DNA-PKcs (Blunt et al. 1995; Kirchgessner et al. 1995; Peterson et al. 1995b). Consistent with this, a radiosensitive human cell line (MO59J) was found to be defective in DNA-PKcs expression and DNA-PK activity (Lees-Miller et al. 1995). Subsequent work showed cells of IR5 and IR7 to harbor inactivating mutations in the genes for Ku80 and DNAPKcs, respectively, and revealed that inactivation of Ku80 leads to a dramatic destabilization of both itself and Ku70 (Errami et al. 1996, 1998a,b; Blunt et al. 1996; Danska et al. 1996; Araki et al. 1997; Singleton et al. 1997; Peterson et al. 1997; Fukumura et al. 1998; Priestley et al. 1998). It was therefore concluded that mutations in Ku80 or DNA-PKcs lead to IR hypersensitivity, that XRCC5 and XRCC7 encode Ku80 and DNA-PKcs, respectively, and that DNA-PK is a crucial component of the mammalian DNA DSB repair apparatus. None of the original rodent cell lines was defective in $\mathrm{Ku} 70$, but it was assumed that cells lacking it would have a similar phenotype to those in IR4-7. This has been confirmed by targeted disruption of the gene for Ku70 in mouse cells, allowing such cells to be designated IR6 and the gene for $\mathrm{Ku} 70$ to be designated XRCC6 (Gu et al. 1997). In other work, the XRCC4 gene product was cloned, and IR4 cells were shown to be deleted for this gene (Li et al. 1995).
Although the sequence of the 334-amino acid XRCC4 protein did not initially yield insights into its mode of action, subsequent studies revealed that it forms a tight and specific association with DNA ligase IV (Critchlow et al. 1997; Grawunder et al. 1997), a protein which has itself been revealed recently to function in DNA NHEJ (Barnes et al. 1998; Frank et al. 1998; Grawunder et al. 1998)

Under most circumstances, the predominant mechanism for DNA DSB repair in mammalian cells is that of NHEJ, and it is in this process that the IR4-7 mutants are defective. Characteristically, NHEJ does not need extensive homologies between the recombining DNA molecules nor does it require an undamaged DNA partner; it is therefore distinct from the well-characterized homologous recombination pathway of DSB repair (for reviews, see Chu 1997; Critchlow and Jackson 1998; Kanaar et al. 1998). In contrast to the situation in mammalian cells, $S$. cerevisiae mainly repairs DSBs by homologous recombination-this requires genes in the RAD52 epistasis group (Kanaar et al. 1998). Nevertheless, recent work has shown yeast to have a NHEJ pathway that is highly related to that in higher eukaryotes. Thus, yeast possesses homologs of Ku70 and Ku80 (Yku70p and Yku80p, respectively; also termed Hdf1p and Hdf2p, respectively) that exist in a heterodimeric complex. Furthermore, loss of either yeast $\mathrm{Ku}$ subunit leads to IR hypersenstivity in rad52 mutant backgrounds and causes NHEJ defects as ascertained by an in vivo plasmid repair assay (Boulton and Jackson 1996a,b; Feldmann et al. 1996; Mages et al. 1996; Milne et al. 1996; Siede et al. 1996). Yeast also contains homologs of XRCC4 and DNA ligase IV (Lif1p and Lig4p or Dnl4p, respectively), and these have been shown to function in the Ku pathway of NHEJ (Schar et al. 1997; Teo and Jackson 1997; Wilson et al. 1997; Herrmann et al. 1998; Ramos et al. 1998). No clear homolog of DNA-PKcs exists in the $S$. cerevisiae genome however, suggesting either that its functions are not conserved or are mediated by other proteins.

Recently, several other yeast NHEJ components have been identified, including the nuclease complex containing Rad50p, Mre11p, and Xrs2p (Milne et al. 1996; Boulton and Jackson 1998). Human homologs of Rad50p and Mre11p have also been identified and have been linked to DNA DSB repair by way of the fact that they become targeted to sites of IR-induced damage in vivo (Maser et al. 1997; Nelms et al. 1998). Moreover, it has been established that human Rad50 and Mre11 exist in a complex with NBS1 (also called Nibrin), a protein whose deficiency leads to the rare human genetic disorder called Nijmegen breakage syndrome (NBS) (Carney et al. 1998; Matsuura et al. 1998b; Varon et al. 1998). NBS is characterized by chromosomal instability, developmental abnormalities, and cancer predisposition (for review, see Featherstone and Jackson 1998). In addition, defects in NBS1 are reported to lead to impaired induction of p53 in response to IR, thus providing an exciting potential linkage between DNA DSB rejoining and DNA damage signaling (Jongmans et al. 1997; Matsuura et al. 1998b). Three other yeast proteins shown to be required for effi- 
cient NHEJ are the heterochromatin components Sir2p, Sir3p, and Sir4p (Tsukamoto et al. 1997; Boulton and Jackson 1998). An interaction between yKu70p and Sir4p in the yeast two-hybrid system (Tsukamoto et al. 1997), has suggested that Ku recruits the Sir protein complex to DNA DSBs in vivo and that this might contribute to NHEJ, either by preventing access to nucleases or by facilitating the juxtaposition of the two DNA termini via chromatin condensation. Although such models are attractive, recent work from Rine and colleagues has cast doubt on a direct involvement of the Sir proteins in NHEJ and has suggested that their effects are, at least in part, mediated by influencing the mating type status of the yeast cell (Åström et al. 1999).

There are a variety of other ways in which $\mathrm{Ku}$ and DNA-PKcs might function in DNA NHEJ (for more extensive discussions, see Chu 1997; Critchlow and Jackson 1998; Kanaar et al. 1998). Most obviously perhaps, the fact that $\mathrm{Ku}$ can bind with great avidity to DNA ends suggests that it directly recognizes DNA DSBs in vivo and, in higher eukaryotes, recruits DNA-PKcs to such sites. Once bound, Ku or the DNA-PK complex might then protect the ends from nucleolytic degradation, as suggested by the ability of Ku-containing complexes to exclude nucleases in vitro (Mimori and Hardin 1986; DeVries et al. 1989; Gottlieb and Jackson 1993). Consistent with this idea, linear DNA transfected into IR5 cells is more susceptible to end degradation than in control cells (Liang and Jasin 1996), and the rare NHEJ products that are generated in mammalian or yeast cells lacking $\mathrm{Ku}$ have generally suffered large deletions of terminal sequences before ligation has taken place (for example, see Taccioli et al. 1993; Boulton and Jackson 1996b). Nevertheless, and as discussed later, $V(D) I$ recombination intermediates are relatively stable in the absence of $\mathrm{Ku}$ or DNA-PKcs, indicating that in this case at least, $\mathrm{Ku}$ or DNA-PKcs are not required for DNA end stabilization (Zhu et al. 1996). Another way that Ku/DNA-PKcs could potentiate end ligation is by tethering two DNA ends together. Indeed, $\mathrm{Ku}$ is able to promote interactions between two DNA termini (Cary et al. 1997) and can enhance end ligation by eukaryotic DNA ligases in vitro (Ramsden and Gellert 1998). Notably, in situations in which NHEJ cannot occur simply by the direct ligation of mutually complementary 5'- or 3'-overhanging termini, repair products tend to suffer short deletions and become rejoined at sites of short direct repeats of microhomology. It is tempting to speculate that the weak helicase functions of $\mathrm{Ku}$ could play a role in dissociating the two strands of the DNA ends to allow such microhomology alignments to be produced, although it should again be noted that no clear phenotype has yet been described for Ku proteins mutated in the proposed helicase motifs (Jin and Weaver 1997; Singleton et al. 1997). Furthermore, it is clear that microhomology directed repair does occur in Ku80 knockout cells (Bogue et al. 1997). Therefore, if Ku does play a role in this pathway, it cannot be essential.

Once positioned at the DNA DSB, Ku and DNA-PKcs might then recruit other NHEJ factors, or, in the case of the DNA-PK holoenzyme, might regulate the activities of these components by phosphorylation. Suggestive that this may indeed be the case are the observations that DNA-PK is able to phosphorylate XRCC4 in vitro and that the XRCC4/ligase IV complex can interact directly or indirectly with DNA-PK in crude nuclear extracts (Critchlow et al. 1997; Leber et al. 1998). Another complex that might be recruited and/or activated by $\mathrm{Ku}$ or DNA-PKcs is that containing Rad50, Mre11, and NBS1 (Rad50p, Mre11p, and Xrs2p in yeast), whose nuclease activities may be critical in 'tidying up' damaged DNA termini before they can be ligated together (Furuse et al. 1998; Paull and Gellert 1998; Trujillo et al. 1998). Recent data have indicated that the endonuclease function of Mre11p is not needed for NHEJ of restriction enzyme-generated DNA DSBs (Moreau et al. 1999), but whether this is also the case for the repair of noncomplementary ends or IR-induced damage has not been reported. Finally in regard to the mechanism of $\mathrm{Ku}$ and DNA-PKcs action in NHEJ, it is possible that they act to dissociate repair factors from the DNA after their job is complete, or help to remove from the DNA other proteins, such as recombination factors that might block the repair process (Zhu et al. 1996). In this context, it is noteworthy that DNA-PK is capable of repressing transcription by RNA polymerase I in vitro (Kuhn et al. 1995; Labhart 1995). Also, autophosphorylation leads to the dissociation of DNA-PKcs from DNA-bound Ku (Chan and Lees-Miller 1996). If such an autophosphorylation were to take place in trans, it could provide a mechanism for removing DNA-PKcs only when two DNA ends are brought into close proximity. In addition to possibly triggering repair-associated functions of $\mathrm{Ku}$, this could provide an elegant mechanism for coupling repair to inactivation of DNA-PK-mediated DNA damage signaling (discussed below).

To help us in understanding the molecular details of DNA NHEJ, the establishment of biochemical systems that accurately reflect this process will be of importance. A potentially major step towards this goal is the recent development of a mammalian cell-based system that appears to be dependent on DNA-PKcs, Ku, and the ligase IV/XRCC4 complex and also requires other, as-yet-uncharacterized, components (Baumann and West 1998). A recently developed Xenopus NHEJ system also appears to be dependent on functional DNA-PK catalytic activity (Gu et al. 1996; 1998). In addition to allowing the identification and characterization of NHEJ components, such systems may be of great use in studying the control of NHEJ during the cell cycle and in analyzing interfaces between NHEJ and other processes, such as transcription and the control of chromatin structure.

\section{Role of DNA-PKes and $\mathrm{Ku}$ in DNA-damage signaling}

Despite DNA-PK having been identified for $>10$ years, the nature of its physiological target(s) is still uncertain. Numerous in vitro substrates have been identified, which include a variety of transcription factors, most notably p53 (discussed in more detail below), the RNA 
polymerase II large subunit carboxy-terminal domain (CTD) and chromatin components (for review see Anderson and Lees-Miller 1992). However, whether any or all of these are functional DNA-PK targets in vivo is not yet clear. The $34-\mathrm{kD}$ subunit of replication protein A (RPA) is also a good candidate for a DNA-PK target (Brush et al. 1994) although conflicting reports exist in the literature as to whether it is indeed phosphorylated by DNA-PK in vivo (Boubnov and Weaver 1995; Fried et al. 1996). Other potential DNA-PK targets include components of the DNA NHEJ machinery, such as XRCC4, which is an effective substrate for DNA-PK in vitro and is known to be a phosphoprotein in vivo (Critchlow et al. 1997; Leber et al. 1998). Furthermore, as discussed above, both $\mathrm{Ku}$ subunits and DNA-PKcs are subject to DNA-PK phosphorylation in vitro.

Key to elucidating the functional consequences of DNA-PK-mediated phosphorylation events will be the identification and subsequent mutagenesis of phosphorylation sites. Such studies will be facilitated by DNA-PK target consensus sequences having been defined. The available data indicate that DNA-PK has a marked preference for Ser or Thr residues preceding (and to a lesser extent preceded by) a Gln residue, and that phosphorylation is potentiated by adjacent acidic residues and tends to be inhibited by basic residues (Anderson and Lees-Miller 1992; Bannister et al. 1993). Unfortunately from a predictive standpoint, DNA-PK does not recognize all sequences conforming to this consensus, probably due to conformational constraints. It is also clear that not all DNA-PK target sites conform to this consensus.

Being a DNA damage-activated protein kinase, DNAPK is inherently well suited to functioning in DNA damage signaling. Thus, DNA-PK activation in response to IR or other agents could trigger signaling pathways that result in apoptosis or cell cycle checkpoint arrest-such responses being designed to prevent the proliferation of potentially mutated cells or to allow DNA repair to occur prior to DNA replication or mitosis (for review, see Elledge 1996). Consistent with this idea, an efficient target for DNA-PK in vitro is p53, a factor whose levels and activity are induced in response to DNA damage and which plays key roles in triggering apoptosis or cell cycle arrest in such circumstances (for review, see Ko and Prives 1996). Furthermore, DNA-PK phosphorylates serine 15 and serine 37 of p53 in vitro (Lees-Miller et al. 1990, 1992), and this has been reported to destabilize interactions between p53 and $\mathrm{Mdm} 2$, a protein that negatively regulates p53 in vivo by targeting it for ubiquitin-mediated proteolysis (Haupt et al. 1997; Kubbutat et al. 1997; Shieh et al 1997). Initial analyses of cells defective in DNA-PK components have, however, shown them to have intact DNA damage checkpoints and to be capable of mediating p53 stabilization in response to IR (Bogue et al. 1996; Fried et al. 1996; Guidos et al. 1996; Huang et al. 1996; Nacht et al. 1996; Candeias et al. 1997; Rathmell et al. 1997; Shieh et al. 1997). Nevertheless, recent work using certain DNA-PKcs defective cell lines has indicated that DNA-PK activation in response to DNA damage is necessary, but not sufficient, for the activation of sequence specific DNA binding by p53 by an as yet undefined mechanism (Woo et al. 1998). However, new data now exist questioning the interpretation of this study (M. Hubank and G.Wahl pers. comm.). The above studies indicate that DNA-PK either does not regulate p53 through serine 15 phosphorylation or does so in a redundant manner with other proteins. In this regard, it has been shown recently that the DNA-PK related proteins ATM and ATR are also capable of phosphorylating p53 on serine 15 in vitro (Banin et al. 1998; Canman et al. 1998; Khanna et al. 1998), and serine p53 phosphorylation in response to DNA-damaging agents is debilitated in cells impaired or lacking ATM or ATR function (Kastan et al. 1992; Tibbets et al. 1999). Thus, it may be that ATM, ATR, and possibly DNA-PK signal different but partially overlapping types of DNA damage to a common p53 effector pathway (Fig. 1). Notably, DNA-PK has been demonstrated to be capable of phosphorylating Mdm2 in vitro (Mayo et al. 1997), sug-

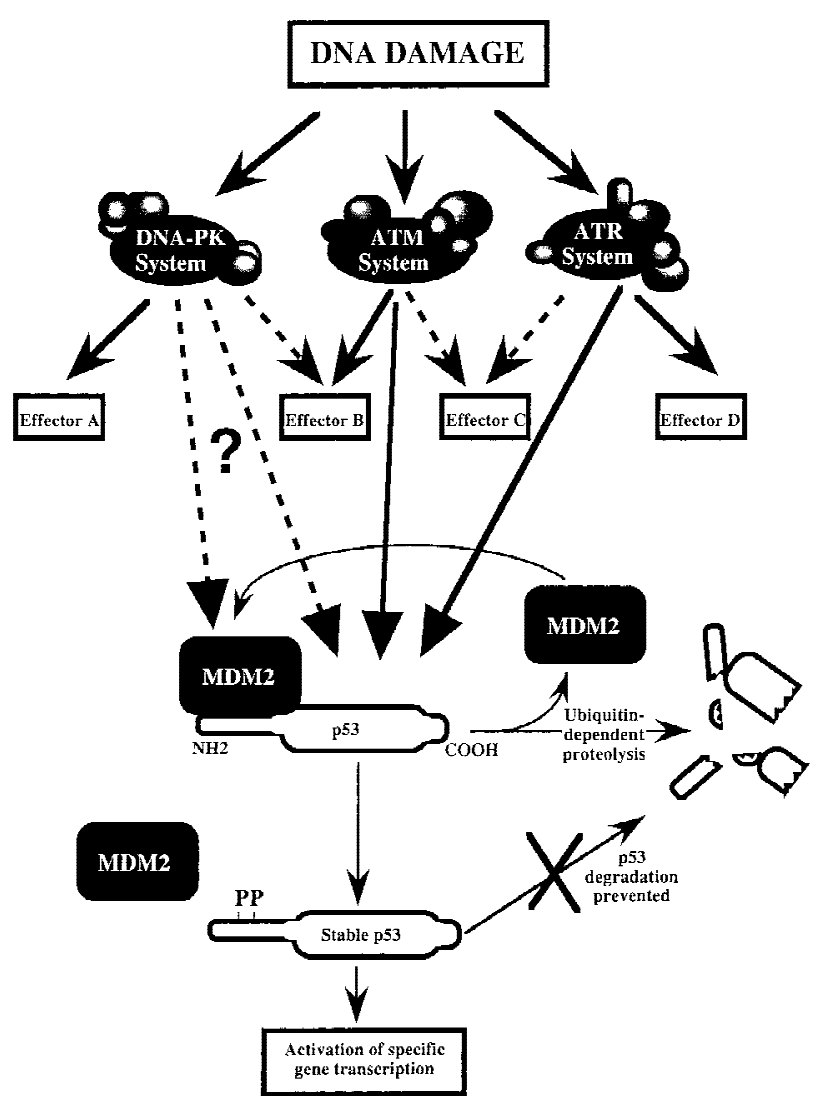

Figure 1. A hypothetical model whereby signaling to p53 by the DNA-PK, ATM and ATR systems leads to phosphorylation at the amino terminus of p53. These phosphorylation events result in the disruption of the p53/MDM2 interaction, and hence lead to p53 protein stabilization and to p53-dependent downstream events. The three DNA damage responsive systems may also signal to other effectors. The arrow from DNAPK to Mdm2 indicates another potential mechanism by which DNA-PK and its relatives might modulate p53 activity or stability. 
gesting that this might be an alternative mechanism by which DNA-PK, ATM, or ATR regulate p53 activity.

\section{Knockout mouse models for DNA-PK components}

The first mutant mouse model for analysing DNA-PK function was the spontaneously arising SCID (severe combined immunodeficiency) mouse (Bosma and Carroll 1991). The SCID mouse has a nonfunctional immune system, due to an almost complete lack of mature B and $\mathrm{T}$ lymphocytes. Analysis of the SCID defect revealed that it occurs at the level of site-specific $V(D) J$ recombination (Lieber et al. 1988). Briefly, this process involves the rearrangement, by a cut-and-paste mechanism, of variable $(V)$, diversity $(D)$, and joining $(J)$ segments of immunoglobulin and $\mathrm{T}$-cell receptor genes, leading to the production of nonfunctional signal joints and to coding joints that encode the highly variable-antigen binding regions of the antigen receptors. The first enzymatic step of $V(D) J$ recombination is the formation, by the RAG1 and RAG2 proteins (McBlane et al. 1995), of DNA DSBs between a pair of signal and coding segments. This reaction yields blunt-ended signal termini and coding termini that have covalently sealed hairpin structures (for review, see Ramsden et al. 1997). The second stage of $V(D) J$ recombination, in which the RAG proteins appear to play a role (Agrawal and Schatz 1997), involves ligation of the recombination intermediates. For the signal ends, this appears to take place through simple end joining, whereas coding joining is more complex and requires hairpin opening before ligation can ensue. In SCID cells, the generation of DSBs still occurs but the formation of coding joints is profoundly impaired, leading to an accumulation of coding $V(D) J$ recombination intermediates. In contrast, SCID cells produce signal joints but with reduced efficiency (summarized in Bogue et al. 1998).

The inability of SCID mice to correctly process and ligate coding $V(D) J$ intermediates suggested a link between $V(D) J$ recombination and DSB repair. Indeed, SCID mice and cells derived from them are hypersensitive to IR, display defects in joining of IR-induced DNA DSBs, and fall into the IR sensitivity complementation group IR7 (Fulop and Phillips 1990; Biedermann et al. 1991; Hendrickson et al. 1991). Biochemical and genetic studies revealed a loss of DNA-PKcs function in SCID cells (Blunt et al. 1995; Kirchgessner et al. 1995; Peterson et al. 1995b). This results from a mutation in the DNAPKcs gene that converts the Tyr-4046 codon into a stop codon, creating a truncated protein missing the last 83 amino acid of the kinase domain (Blunt et al. 1996; Danska et al. 1996; Araki et al. 1997). Although this mutated protein is highly unstable, it is still present at detectable levels $(\sim 5 \%$ of the levels of normal protein), raising the possibility that SCID cells retain residual DNA-PKcs function (Danska et al. 1996).

The pronounced effect of DNA-PKcs loss on coding but not signal joint formation in mice, and the accumulation of coding but not signal recombination intermediates in SCID cells suggests that there are mechanistic differences between coding and signal joint formation. Because coding but not signal ends go through a hairpin intermediate, DNA-PKcs might not be required for simple end-joining reactions but may be necessary for the processing of more complicated substrates before they can be ligated. For example, DNA-PKcs might help recruit or activate the Rad50/Mre11 complex, which is involved in NHEJ in yeast and can open DNA hairpins (Paull and Gellert 1998; Trujillo et al. 1998). Alternatively, DNA-PKcs might control the hairpin opening activities of the RAG1 /RAG2 complex (Zhu et al. 1996). Notably, hairpins bind to but do not activate DNA-PK (Smider et al. 1998). This raises the possibility that DNA-PK kinase functions are only triggered after the hairpin opening stage. Although the above models for DNA-PKcs function may be correct, recent work has indicated that, although there appear to be some celltype specific differences, DNA-PKcs-deficient cells are often impaired to some degree in signal joint formation (Bogue et al. 1998; Errami et al. 1998b). Furthermore, the Arabian horse SCID mutant (equine SCID), which arose through loss of the carboxy terminal 967 amino acids of the DNA-PKcs protein (Wiler et al. 1995; Shin et al. $1997)$ is defective in both $V(D) J$ signal and coding joint formation. On balance, the available data support the idea that the differential impact of DNA-PKcs loss on coding and signal joint formation is largely quantitative rather than qualitative.

Recently, knockout mice have been generated that are null for DNA-PKcs (DNA-PKcs ${ }^{-/-}$; Jhappan et al. 1997; Gao et al. 1998) or ablated for its kinase domain (DNA$\mathrm{PKcs}^{\mathrm{kin}-{ }^{-}}$; Taccioli et al. 1998). Like SCID, these mice are immunodeficient and are severely defective in $V(D) J$ coding but not signal joint formation. However, some phenotypic differences do appear to exist between these knockout mice and SCID animals. For example, DNA$\mathrm{PKcs}^{\text {kin- } /-}$ mice produce measurable $\mathrm{CD} 4^{+} \mathrm{CD} 8^{+}$doublepositive (DP) thymocytes, in contrast to barely detectable levels of these in the SCID mouse (Taccioli et al. 1998). The DNA-PKcs ${ }^{-/-}$mice generated by the chance integration of a yeast transgene into the DNA-PKcs gene, also produces DP thymocytes (Jhappan et al. 1997) but DP thymocytes were not reported in the other DNA$\mathrm{PKcs}^{-/-}$mouse (Gao et al. 1998). Another difference is that the DNA-PKcs knockout mice of Jhappan et al. (1997) but not SCID mice show a significantly increased incidence of thymic lymphoma (see below). Interestingly, sublethal irradiation of SCID animals also leads to an elevation of DP thymocytes and thymic lymphoma (Danska et al. 1994). These data are consistent with the idea that the SCID mouse retains some residual DNAPKcs function, and/or there is an alternative error-prone pathway(s) for resolving $V(D) J$ recombination intermediates that can lead to the generation of oncogenic chromosomal translocations.

Mice have also been produced that are defective in Ku70 or Ku80 (Nussenzweig et al. 1996; Zhu et al. 1996; $\mathrm{Gu}$ et al. 1997; Ouyang et al. 1997). Consistent with biochemical studies, the loss of one Ku subunit leads to undetectable or severely reduced levels of the other and 
to undetectable Ku DNA end-binding activity (Gu et al. 1997). Also as predicted, Ku70- and Ku80-deficient animals are very alike phenotypically and share many features with SCID and DNA-PKcs knockout mice. Thus, $\mathrm{Ku}$-deficient animals are hypersensitive to IR (Nussenzweig et al. 1997). Furthermore, the dose of IR required for $50 \%$ mortality of $\mathrm{Ku} 80^{-/-}$, adult mice (2-4 months old) is similar to that for SCID mice (Biedermann et al. 1991). Younger $\mathrm{Ku} 80^{-/-}$animals, however, are reported to be significantly more hypersensitive to IR than SCID mice (Nussenzweig et al. 1997). Ku-deficient animals also have severe combined immunodeficiency, and fail to generate functional $\mathrm{T}$ and $\mathrm{B}$ lymphocytes effectively, at least in large part due to defects in the ligation-dependent stages of $V(D) J$ recombination (Nussenzweig et al. 1996; Zhu et al. 1996). In contrast to SCID and DNAPKcs-null mice, however, signal joint formation is also highly defective in Ku-negative animals. These findings are in line with data from Ku80-deficient rodent cell lines (e.g., xrs6), which have revealed severe defects in both signal and coding joint formation (Pergola et al. 1993; Taccioli et al. 1993, 1994). A detailed analysis of one $\mathrm{Ku} 80^{-/-}$mouse revealed that both blunt full-length signal ends and hairpin coding ends accumulate (Zhu et al. 1996; Han et al. 1997), suggesting that $\mathrm{Ku}$ is not required to protect the ends of these intermediates from degradation and, instead, may help recruit the appropriate ligation machinery and/or help to dissociate the RAG-DNA complex before end ligation can ensue.

A characteristic frequently observed in mice deficient in DNA-PK components is lymphoma. Early studies revealed that SCID mice have a low but significantly elevated incidence of lymphoma (Custer et al. 1985). Moreover, irradiation of SCID mice with sublethal doses of IR results in some rescue of T-cell development and thymic lymphoma in all animals (Danska et al. 1994). Similarly, SCID animals bred to possess homozygous mutations in p53 also display rescued T-cell development and an increased incidence of lymphoma/leukemia (Bogue et al. 1996; Guidos et al. 1996; Nacht et al. 1996). Taken together, these data suggest the existence of alternative recombination pathways, which are normally repressed, that are able to resolve $V(D) J$ recombination intermediates and can lead to T-cell tumorigenesis. Consistent with this idea, loss of PARP, a known anti-recombinogenic factor, also results in rescue of $\mathrm{T}$ cell development and T-cell lymphoma in SCID backgrounds (Morrison et al. 1997). Recently, complete penetrance of T-cell lymphoma has been demonstrated for animals knocked out for DNA-PKcs function (Jhappan et al. 1997), and a very similar phenotype exists for $\mathrm{Ku} 70^{-/-}$mice, where the majority of animals develop T-cell lymphoma (Gu et al. 1997; Li et al. 1998). Fibroblasts derived from $\mathrm{Ku} 70^{-/-}$mice form foci in culture and harbor chromosomal aberrations indicated by elevated levels of sister chromatid exchanges ( $\mathrm{Li}$ et al. 1998). Furthermore, Ku $70^{-/-}$cells derived from transformed foci are able to produce tumours in nude mice. To date, however, there is no report of lymphoma in $\mathrm{Ku} 80^{-/-}$mice.
How is it that loss of DNA-PKcs or Ku70 can lead to lymphoma in mice whereas loss of Ku80 apparently does not? One hint may come from the observation that residual coding joints are detected and some mature $\mathrm{T}$ lymphocytes develop in $\mathrm{Ku} 70^{-/-}$animals and in older SCID mice, but these appear to be fully absent in $\mathrm{Ku} 80^{-/-}$mice. Although other effects on T-cell maturation or tumorigenesis cannot be discounted, an attractive model is that, in the absence of Ku70 or DNA-PKcs, normal constraints on the reactivity of DNA DSBs generated during $V(D) J$ recombination are released. This could allow the DNA ends to undergo recombination reactions that are independent of the DNA-PK system; this would lead to some rescue of $V(D) I$ recombination but might also result in inappropriate recombination events with other loci, some of which may have oncogenic capacity. If this is correct, one would have to postulate that the alternative recombination pathways are suppressed by DNA-PKcs or Ku70 but not by Ku80, and/ or that these alternative pathways employ Ku80. In light of this hypothesis, it will be of interest to see whether lymphomas arise in DNA-PKcs ${ }^{-/-}, \mathrm{Ku} 80^{-/-}$, or in $\mathrm{Ku} 70^{-/-}$, $\mathrm{Ku} 80^{-/-}$double mutant mice, and whether the lymphomas generated in DNA-PKcs mutant or $\mathrm{Ku} 70^{-/-}$backgrounds contain oncogenic chromosomal translocations involving T-cell receptor loci. The fact that Ku70 and DNA-PKcs act as T-cell tumor suppressors in mice raises the possibility that this may also be so in humans. Hinting that this may indeed be the case, citing unpublished data, Li et al. (1998) have reported that 6 out of 17 human lymphomas they tested were found to harbor mutations in the core domain of $\mathrm{Ku} 70$ that is implicated in heterodimerisation with Ku80 and DNA end binding. However, no mutations in DNA-PKcs have been found in human cancers to date.

In line with the existence of multiple DNA DSB repair pathways is the finding that loss of DNA-PKcs function can have different effects in different cell types. In contrast to cells from most tissues in the SCID mouse and fibroblast cell lines derived from SCID mice, DNA$\mathrm{PKcs}^{\text {kin- }- \text { - }}$ or DNA-PK ${ }^{-/}$mice, embryonic stem (ES) cells established from the DNA-PKcs ${ }^{-/-}$mouse are not significantly radiosensitive (Gao et al. 1998). This implies that, unlike the situation in other cell types analyzed, the principal DNA DSB repair pathway(s) operating in ES cells is not dependent on DNA-PKcs. Part of the explanation for this may be that ES cells and possibly certain other stem-cell types employ homologous recombination instead of NHEJ to repair IR-induced DSBs. This is unlikely to be the whole explanation, however, because $\mathrm{Ku} 70^{-1-}$ ES cells are reported to be radiosensitive (Gu et al. 1997a), implying that ES cells use a repair pathway that is Ku70-dependent but DNA-PKcs-independent. Other evidence for such a pathway is the report that Ku-deficient but not DNA-PKcs-deficient cell lines are hypersensitive to etoposide, a topoisomerase II inhibitor that generates DNA DSBs (Jin et al. 1998).

Visually, the most striking phenotype of the Ku-deficient mice is their size: they are only $40 \%-60 \%$ of the weight of control littermates (Nussenzweig et al. 1996; 
Gu et al. 1997b; Ouyang et al. 1997). The observed proportional dwarfism is not due to a reduction in cell size but to a reduction in cell number. Early passage embryonic fibroblasts derived from Ku-deficient animals grow approximately twice as slowly as controls, at least in part due to an increase in the proportion of nondividing but still metabolically active cells in the Ku-deficient cell populations (Nussenzweig et al. 1996; Gu et al. 1997b). A further examination of the impaired cell growth phenotype of $\mathrm{Ku} 80^{-/-}$primary fibroblasts revealed that they sustain DNA damage, arrest at the $G_{1} / S$ or $G_{2} / M$ checkpoints, and then fail to re-enter the cell cycle (Nussenzweig et al. 1996). One explanation for these findings is that Ku-deficient cells have functional DNA damage-induced cell cycle checkpoint mechanisms but fail to re-enter the cell cycle as a result of their inability to repair the damaged DNA effectively. The observed early appearance of nondividing cells in the absence of $\mathrm{Ku}$ has been taken to indicate a potential correlation between senescence and defective DNA DSB repair. However, the dwarf phenotype and apparent replicative senescence have not so far been reported for any of the DNA-PKcs mutant animals, raising the possibility that these phenomena relate to other, as yet undefined, functions of the Ku heterodimer, such as controlling cell growth or affecting telomeric structure (see above). The generation and analysis of mice deficient in DNA-PKcs, $\mathrm{Ku} 70$ or Ku 80 has reinforced the conclusion that the enzyme complex they comprise plays a key role in the detection and repair of DNA DSBs. However, the apparent significant differences in phenotypes between the different animals, most notably, the differences in cancer incidence and animal size, raise the intriguing prospect that the different components of the DNA-PK enzyme have independent additional roles. Such roles could include influences on transcription, chromatin, or, as discussed below, telomeric structure. Nevertheless, it remains a possibility that some of the difference between the various mutant mice reflect different mouse genetic backgrounds and/or differences in housing conditions between the various laboratories.

Animal models have also been valuable in identifying additional functions for DNA-PKcs and $\mathrm{Ku}$ in the process of immunoglobulin heavy chain class switching, the process by which B lymphocytes change the constant region of their antibodies without altering their antigenbinding specificity. Class switching is a programmed genomic rearrangement in which site-specific recombination proceeds between repetitive DNA segments that flank the $5^{\prime}$ sides of the heavy chain constant regions, resulting in exchange of the IgM constant region for that of another antibody class (Harriman et al. 1993). Reminiscent of $V(D) J$ recombination, this process can result in deletion of intervening DNA segments, and appears to be linked to the generation of site-specific DNA DSBs (Wuerffel et al. 1997). Despite the initial suggestion that switch recombination may proceed by homologous recombination, it is not impaired by loss of the homologous recombination component Rad54 (Essers et al. 1997). Instead, recent work has indicated that switch re- combination is highly dependent on DNA-PKcs (Rolink et al. 1996), Ku70 (Manis et al. 1998) and Ku80 (Casellas et al. 1998). Although the mechanistic basis for switch recombination is still unclear, it seems likely that, like $V(D) J$ recombination, it will proceed by a cut-and-paste pathway involving components of the NHEJ apparatus. The results from the class switching studies raise the exciting prospect that the DNA-PKcs-Ku system is also involved in other genomic rearrangements and related events in eukaryotes. In line with this proposal, work in Drosophila has revealed a function for $\mathrm{Ku}$ in P-element transposition (Beall and Rio 1996).

\section{Role of $\mathrm{Ku}$ in telomere maintenance}

Telomeres are specialized structures situated at the natural ends of linear eukaryotic chromosomes, and serve as caps to prevent chromosomal termini from being degraded by endogenous nucleases or being recognized as DNA damage (for review, see Shore 1998). In most eukaryotes, telomeres consist of tandem copies of simple repeat sequences that are synthesized through a non-DNA-templated mechanism by the enzyme telomerase. Recently, the use of $S$. cerevisiae as a system to study Ku function has revealed a role for this protein in telomere length maintenance. Initial work revealed that yeast defective in either Ku subunit have shortened telomeres; this corresponding to a loss of $\sim 60 \%$ of the telomeric repeats (Boulton and Jackson 1996; Porter et al. 1996). At first, this was seen as somewhat puzzling why would the yeast cell want to recruit a DNA NHEJ repair factor to telomeres, because telomeres actually protect chromosomal termini from engaging in NHEJ events? It now appears that the function of $\mathrm{Ku}$ in telomere length control is, at least in part, independent of its role in the NHEJ pathway, as disruption of the gene for ligase IV, which causes a DSB repair defect essentially the same as that in the absence of $\mathrm{Ku}$, does not lead to telomere shortening (Teo and Jackson 1997). It has also been shown that Ku does not function in the same telomere maintenance pathway as telomerase nor as the Rad50p/Mre11p complex (Nugent et al. 1998).

Although the precise function of $\mathrm{Ku}$ in telomeric functions is as yet unclear, $\mathrm{Ku}$ does appear to be associated physically with telomeric DNA, and regulates the precise structure of telomeric termini, possibly via controlling the access of nucleases and recombinases (Gravel et al. 1998; Polotnianka et al. 1998). In addition, recent studies have shown that $\mathrm{Ku}$ is involved in the tethering of yeast telomeres to the nuclear periphery (Laroche et al. 1998). Yeast defective in Ku have also been found to be defective in telomeric silencing, the process in which genes placed in the vicinity of a telomere are subject to transcriptional repression (Boulton and Jackson 1998; Laroche et al. 1998; Nugent et al. 1998). An attractive explanation for the available data on telomeric silencing is that $\mathrm{Ku}$ helps to establish the transcriptionally silent heterochromatin-like state that normally exists in yeast telomeric DNA. Consistent with this proposal, Yku70p has been shown to interact in the yeast two-hybrid assay 
with Sir4p (Tsukamoto et al. 1997). Sir4p forms a complex with Sir2p and Sir3p and, through associations with Rap $1 \mathrm{p}$ and the amino termini of histones $\mathrm{H} 3$ and $\mathrm{H} 4$, can establish a heterochromatin like structure at the telomere (for review, see Grunstein 1997). It will clearly be of great interest to establish whether Ku functions similarly in higher eukaryotes.

\section{Future directions}

Through a combination of biochemical, cell biological, and genetic approaches, it has become clear that DNA$\mathrm{PK}$ is a key player in DNA DSB repair. In addition, the available evidence suggests that DNA-PK components are involved in other processes, such as controlling chromatin structure and telomeric integrity. With the rich resources of reagents that are now available and the intense interest in this fascinating enzyme, one can confidently predict that there will be rapid progress towards gaining an even better understanding of DNA-PK and its associated proteins in the next few years. Of particular importance will be the identification of novel DSB repair components that operate in conjunction with DNA-PK, and studies investigating the links between DNA-PK and processes such as telomere structure, chromatin and transcription. Also of great importance will be the detailed determination of the structure of DNA-PK and its associated components, and establishing precisely how the DNA-PK enzyme is activated by DNA damage. In addition to providing insights into DNA-PK-associated functions, such studies are likely to provide important information into how structurally and functionally related kinases, such as ATM and ATR, function in the recognition and signaling of genomic damage.

\section{Acknowledgments}

Members of the Jackson laboratory are thanked for the many fruitful discussions on DNA-PK and related issues. In particular, we thank Carol Featherstone, Fabrizio d'Adda di Fagagna, Susan Critchlow, and Andrew McAinsh for their critical evaluation of the review. G.C.M.S. was supported by project grant SP2143/0501 from the Cancer Reseach Campaign.

\section{References}

Agrawal, A. and D.G. Schatz. 1997. RAG1 and RAG2 form a stable postcleavage synaptic complex with DNA containing signal ends in V(D)J recombination. Cell 89: 43-53.

Ajmani, A.K., M. Satoh, E. Reap, P.L. Cohen, and W.H. Reeves. 1995. Absence of autoantigen $\mathrm{Ku}$ in mature human neutrophils and human promyelocytic leukemia line (HL 60) cells and lymphocytes undergoing apoptosis. J. Exp. Med. 181: 2049-2058.

Anderson, C.W. and S.P. Lees-Miller. 1992. The nuclear serine/ threonine protein kinase DNA-PK. Crit. Rev. Eukaryot. Gene Expr. 2: 283-314.

Apone, L.M., C.A. Virbasius, F.C.P. Holstege, J. Wang, R.A. Young, and M.R. Green. 1998. Broad, but not universal, transcriptional requirement for yTAF(II)17, a histone H3-like TAF(II) present in TFIID and SAGA. Mol. Cell 2: 653-661.

Araki, R., A. Fujimori, K. Hamatani, K. Mita, T. Saito, M. Mori, R. Fukumura, M. Morimyo, M. Muto, M. Itoh, K. Tatsumi, and M. Abe. 1997. Nonsense mutation at Tyr 4046 in the DNA-dependent protein kinase catalytic subunit of severe combined immune deficiency mice. Proc. Natl. Acad. Sci. 94: $2438-2443$.

Åström, S.U., S.M. Okamura, and J. Rine. 1999. Yeast cell-type regulation of DNA repair. Nature 397: 310.

Banin, S., L. Moyal, S.Y. Shieh, Y. Taya, C.W. Anderson, L. Chessa, N.I. Smorodinsky, C. Prives, Y. Reiss, Y. Shiloh, and Y. Ziv. 1998. Enhanced phosphorylation of p53 by ATM in response to DNA damage. Science 281: 1674-1677.

Bannister, A.J., T.M. Gottleib, T. Kouzarides, and S.P. Jackson. 1993. c-jun is phosphorylated by the DNA-dependent protein kinase in vitro: Definition of the minimal kinase recognition motif. Nucleic Acids Res. 21: 1289-1295.

Barnes, D.E., G. Stamp, I. Rosewell, A. Denzel, and T. Lindahl. 1998. Targeted disruption of the gene encoding DNA ligase IV leads to lethality in embryonic mice. Curr. Biol. 8: 13951398.

Baumann, P. and S.C. West. 1998. DNA end-joining catalyzed by human cell-free extracts. Proc. Natl. Acad. Sci. 95: 14066-14070.

Beall, E.L. and D.C. Rio. 1996. Drosophila IRBP/Ku p70 corresponds to the mutagen sensitive mus309 gene and is involved in P-element excision in vivo. Genes \& Dev. 10: $921-$ 933.

Bharti, A., S.K. Kraeft, M. Gounder, P. Pandey, S.F. Jin, Z.M. Yuan, S.P. Lees-Miller, R. Weichselbaum, D. Weaver, L.B. Chen, D. Kufe, and S. Kharbanda. 1998. Inactivation of DNA-dependent protein kinase by protein kinase C delta: Implications for apoptosis. Mol. Cell. Biol. 18: 6719-6728.

Biedermann, K.A., J.R. Sun, A.J. Giaccia, L.M. Tosto, and J.M. Brown. 1991. SCID mutation in mice confers hypersensitivity to ionizing radiation and a deficiency in DNA doublestrand break repair. Proc. Natl. Acad. Sci. 88: 1394-1397.

Bliss, T.M. and D.P. Lane. 1997. Ku selectively transfers between DNA molecules with homologous ends. I. Biol. Chem. 272: 5765-5773.

Blunt, T., N.J. Finnie, G.E. Taccioli, G.C.M. Smith, J. Demengeot, T.M. Gottlieb, R. Mizuta, A.J. Varghese, F.W. Alt, P.A. Jeggo, and S.P. Jackson. 1995. Defective DNA-dependent protein kinase activity is linked to $\mathrm{V}(\mathrm{D}) \mathrm{J}$ recombination and DNA repair defects associated with the murine SCID mutation. Cell 80: 813-823.

Blunt, T., D. Gell, M. Fox, G.E. Taccioli, A.R. Lehmann, S.P. Jackson, and P.A. Jeggo. 1996. Identification of a nonsense mutation in the carboxyl terminal region of DNA-dependent protein kinase catalytic subunit in the SCID mouse. Proc. Natl. Acad. Sci. 93: 10285-10290.

Bogue, M.A., C.M. Zhu, E. AguilarCordova, L.A. Donehower, and D.B. Roth. 1996. p53 is required for both radiation induced differentiation and rescue of $\mathrm{V}(\mathrm{D}) \mathrm{J}$ rearrangement in SCID mouse thymocytes. Genes \& Dev. 10: 553-565.

Bogue, M.A., C.Y. Wang, C.M. Zhu, and D.B. Roth. 1997. V(D)J recombination in Ku86-deficient mice: Distinct effects on coding, signal, and hybrid joint formation. Immunity 7: 3747.

Bogue, M.A., C. Jhappan, and D.B. Roth. 1998. Analysis of variable (diversity) joining recombination in DNA-dependent protein kinase (DNA-PK)-deficient mice reveals DNA-PK independent pathways for both signal and coding joint formation. Proc. Nat1. Acad. Sci. 95: 15559-15564.

Bosma, M.J. and A.M. Carroll. 1991. The SCID mouse mutant definition, characterization, and potential uses. Annu. Rev. Immunol. 9: 323-350.

Boubnov, N.V. and D.T. Weaver. 1995. SCID cells are deficient in $\mathrm{Ku}$ and replication protein A phosphorylation by the 
DNA-dependent protein kinase. Mol. Cell. Biol. 15: 57005706.

Boubnov, N.V., K.T. Hall, Z. Wills, S.E. Lee, D.M. He, D.M. Benjamin, C.R. Pulaski, H. Band, W. Reeves, E.A. Hendrickson, and D.T. Weaver. 1995. Complementation of the ionizing radiation sensitivity, DNA end binding, and $\mathrm{V}(\mathrm{D}) \mathrm{J}$ recombination defects of double-strand break repair mutants by the p $86 \mathrm{Ku}$ autoantigen. Proc. Natl. Acad. Sci. 92: 890894.

Boulton, S.J. and S.P. Jackson. 1996a. Identification of a Saccharomyces cerevisiae Ku80 homolog: Roles in DNA doublestrand break rejoining and in telomeric maintenance. Nucleic Acids Res. 24: 4639-4648.

1996b. Saccharomyces cerevisiae Ku70 potentiates illegitimate DNA double-strand break repair and serves as a barrier to error prone DNA repair pathways. EMBO I. 15: 5093-5103.

- 1998. Components of the Ku-dependent non-homologous end-joining pathway are involved in telomeric length maintenance and telomeric silencing. EMBO J. 17: 18191828.

Boulton, S., S. Kyle, L. Yalcintepe, and B.W. Durkacz. 1996. Wortmannin is a potent inhibitor of DNA double-strand break but not single-strand break repair in chinese hamster ovary cells. Carcinogenesis 17: 2285-2290.

Brown, E.J., M.W. Albers, T.B. Shin, K. Ichikawa, C.T. Keith, W.S. Lane, and S.L. Schrieber. 1994. A mammalian protein targeted by G1-arresting rapamycin-receptor complex. $\mathrm{Na}$ ture 369: 756-758.

Brunn, G.J., C.C. Hudson, A. Sekulic, J.M. Williams, H. Hosoi, P.J. Houghton, J.C. Lawrence, and R.T. Abraham. 1997. Phosphorylation of the translational repressor PHAS-I by the mammalian target of rapamycin. Science 277: 99-101.

Brush, G.S., C.W. Anderson, and T.J. Kelly. 1994. The DNAactivated protein kinase is required for the phosphorylation of replication protein-A during simian-virus-40 DNA-replication. Proc. Natl. Acad. Sci. 91: 12520-12524.

Cai, Q.Q., A. Plet, J. Imbert, M. Lafagepochitaloff, C. Cerdan, and J.M. Blanchard. 1994. Chromosomal location and expression of the genes coding for $\mathrm{Ku}$ p70 and p 80 in human cell lines and normal tissues. Cytogen. Cell Gen. 65: 221227.

Candeias, S.M., S.K. Durum, and K. Muegge. 1997. p53-dependent apoptosis and transcription of $\mathrm{p} 21$ (wafl/cip1/sdil) in SCID mice following gamma irradiation. Biochimie 79: 607612.

Canman, C.E., D.S. Lim, K.A. Cimprich, Y. Taya, K. Tamai, K. Sakaguchi, E. Appella, M.B. Kastan, and J.D. Siliciano. 1998. Activation of the ATM kinase by ionizing radiation and phosphorylation of p53. Science 281: 1677-1679.

Cao, Q.P., S. Pitt, J. Leszyk, and E.F. Baril. 1994. DNA-dependent ATPase from HeLa cells is related to human $\mathrm{Ku}$ autoantigen. Biochemistry 33: 8548-8557.

Carney, J.P., R.S. Maser, H. Olivares, E.M. Davis, M. LeBeau, J.R. Yates, L. Hays, W.F. Morgan, and J.H.J. Petrini. 1998. The hMre11/hRad50 protein complex and Nijmegen breakage syndrome: Linkage of double-strand break repair to the cellular DNA damage response. Cell 93: 477-486.

Carter, T.H., C.R. Kopman, and C.B.L. James. 1988. DNAstimulated protein phosphorylation In HeLa whole-cell and nuclear extracts. Biochem. Biophys. Res. Comm. 157: 535540.

Carter, T., I. Vancurova, I. Sun, W. Lou, and S. Deleon. 1990. A DNA-activated protein kinase from HeLa cell nuclei. Mol. Cell. Biol. 10: 6460-6471.

Cary, R.B., S.R. Peterson, J.T. Wang, D.G. Bear, E.M. Bradbury, and D.J. Chen. 1997. DNA looping by Ku and the DNAdependent protein kinase. Proc. Natl. Acad. Sci. 94: 42674272.

Cary, R.B., F.Q. Chen, Z.Y. Shen, and D.J. Chen. 1998. A central region of $\mathrm{Ku} 80$ mediates interaction with $\mathrm{Ku} 70$ in vivo. Nucleic Acids Res. 26: 974-979.

Casciolarosen, L.A., G.J. Anhalt, and A. Rosen. 1995. DNAdependent protein kinase is one of a subset of autoantigens specifically cleaved early during apoptosis. J. Exp. Med. 182: $1625-1634$.

Casellas, R., A. Nussenzweig, R. Wuerffel, R. Pelanda, A. Reichlin, H. Suh, X.F. Qin, E. Besmer, A. Kenter, K. Rajewsky, and M.C. Nussenzweig. 1998. Ku80 is required for immunoglobulin isotype switching. EMBO J. 17: 2404-2411.

Chan, D.W. and S.P. Lees-Miller. 1996. The DNA-dependent protein kinase is inactivated by autophosphorylation of the catalytic subunit. J. Biol Chem. 271: 8936-8941.

Chan, D.W., C.H. Mody, N.S.Y. Ting, and S.P. Lees-Miller. 1996. Purification and characterization of the doublestranded DNA-activated protein kinase, DNA-PK, from human placenta. Biochem. Cell Biol. Biochim. Biol. Cell 74: 67-73.

Chiu, M.I., H. Katz, and V. Berlin. 1994. RAPT1, a mammalian homolog of yeast Tor, interacts with the FKBP12-rapamycin complex. Proc. Nat1. Acad. Sci. 91: 12574-12578.

Chiu, C.Y., R.B. Cary, D.J. Chen, S.R. Peterson, and P.L. Stewart. 1998. Cryo EM imaging of the catalytic subunit of the DNA-dependent protein kinase. J. Mol. Biol. 284: 10751081.

Chu, G. 1997. Double-strand break repair. J. Biol. Chem. 272: 24097-24100.

Cimprich, K.A., T.B. Shin, C.T. Keith, and S.L. Schreiber. 1996. cDNA cloning and gene mapping of a candidate human cell cycle checkpoint protein. Proc. Nat1. Acad. Sci. 93: 28502855.

Connelly, M.A., H. Zhang, J. Kieleczawa, and C.W. Anderson. 1996. Alternate splice site utilization in the gene for the catalytic subunit of the DNA-activated protein kinase, DNA-PKcs. Gene 175: 271-273.

- 1998. The promoters for human DNA PKcs (PRKDC) and MCM4: Divergently transcribed genes located at chromosome 8 band q11. Genomics 47: 71-83.

Critchlow, S.E. and S.P. Jackson. 1998. DNA end joining: from yeast to man. Trends Biochem. Sci. 23: 394-398.

Critchlow, S.E., R.P. Bowater, and S.P. Jackson. 1997. Mammalian DNA double-strand break repair protein XRCC4 interacts with DNA ligase IV. Curr. Biol. 7: 588-598.

Custer, A.M., G.C. Bosma, and G.C. Bosma. 1985. Severe combined immunodeficiency (SCID) in the mouse: Pathology, reconstitution, neoplasms. Amer. J. Path. 120: 464-477.

Dabrowski, M., E. Robinson, S.V. Hughes, R. Bland, and M. Hewison. 1998. Differential RNA display identifies novel genes associated with decreased vitamin D receptor expression. Mol. Cell. Endocrinol. 142: 131-139.

Danska, J.S., F. Pflumio, C.J. Williams, O. Huner, J.E. Dick, and C.J. Guidos. 1994. Rescue of T cell-specific V(D)J recombination in SCID mice by DNA damaging agents. Science 266: 450-455.

Danska, J.S., D.P. Holland, S. Mariathasan, K.M. Williams, and C.J. Guidos. 1996. Biochemical and genetic defects in the DNA-dependent protein kinase in murine SCID lymphocytes. Mol. Cell. Biol. 16: 5507-5517.

Devries, E., W. Vandriel, W.G. Bergsma, A.C. Arnberg, and P.C. Vandervliet. 1989. HeLa nuclear protein recognizing DNA termini and translocating on DNA forming a regular DNA multimeric protein complex. J. Mol. Biol. 208: 65-78. 
Dvir, A., S.R. Peterson, M.W. Knuth, H. Lu, and W.S. Dynan. 1992. Ku autoantigen is the regulatory component of a template associated protein kinase that phosphorylates RNA polymerase II. Proc. Natl. Acad. Sci. 89: 11920-11924.

Dvir, A., L.Y. Stein, B.L. Calore, and W.S. Dynan. 1993. Purification and characterization of a template associated protein kinase that phosphorylates RNA polymerase II. I. Biol. Chem. 268: 10440-10447.

Dynan, W.S. and S. Yoo. 1998. Interaction of Ku protein and DNA-dependent protein kinase catalytic subunit with nucleic acids. Nucleic Acids Res. 26: 1551-1559.

Elledge, S.J. 1996. Cell cycle checkpoints: Preventing an identity crisis. Science 274: 1664-1672.

Errami, A., V. Smider, W.K. Rathmell, D.M. He, E.A. Hendrickson, M.Z. Zdzienicka, and G. Chu. 1996. Ku86 defines thje genetic defect and restores $\mathrm{X}$-ray resistance and $\mathrm{V}(\mathrm{D}) \mathrm{J}$ recombination to complementation group 5 hamster cell mutants. Mol. Cell. Biol. 16: 1519-1526.

Errami, A., N.J. Finnie, B. Morolli, S.P. Jackson, P.H.M. Lohmann, and M.Z. Zdzienicka. 1998a. Molecular and biochemical characterization of new x-ray sensitive hamster cell mutants defective in Ku80. Nucleic Acids Res. 26: 4332-4338.

Errami, A., D.M. He, A.A. Friedl, W.J.I. Overkamp, B. Morolli, E.A. Hendrickson, F. EckardtSchupp, M. Oshimura, P.H.M. Lohman, S.P. Jackson, and M.Z. Zdzienicka. 1998b. XR C1, a new $\mathrm{CHO}$ cell mutant which is defective in DNA PKcs, is impaired in both $\mathrm{V}(\mathrm{D}) \mathrm{J}$ coding and signal joint formation. Nucleic Acids Res. 26: 3146-3153.

Essers, J., R.W. Hendriks, S.M.A. Swagemakers, C. Troelstra, J. deWit, D. Bootsma, J.H.J. Hoeijmakers, and R. Kanaar. 1997. Disruption of mouse RAD54 reduces ionizing radiation resistance and homologous recombination. Cell 89: 195-204.

Falzon, M., J.W. Fewell, and E.L. Kuff. 1993. Ebp 80, a transcription factor closely resembling the human autoantigen $\mathrm{Ku}$, recognizes single strand to double-strand transitions in DNA. J. Biol Chem. 268: 10546-10552.

Featherstone, C. and S.P. Jackson. 1998. DNA repair: The Nijmegen breakage syndrome protein. Curr. Biol. 8: R622R625.

Feldmann, H., L. Driller, B. Meier, G. Mages, J. Kellermann, and E.L. Winnacker. 1996. Hdf2, the 2nd subunit of the Ku homolog from Saccharomyces cerevisiae. J. Biol. Chem. 271: 27765-27769.

Finnie, N.J., T.M. Gottlieb, T. Blunt, P.A. Jeggo, and S.P. Jackson. 1995. DNA-dependent protein kinase activity is absent in xrs 6 cells implications for site-specific recombination and DNA double-strand break repair. Proc. Natl. Acad. Sci. 92: 320-324.

Frank, K.M., J.M. Sekiguchi, K.J. Seidl, W. Swat, G.A. Rathbun, H.L. Cheng, L. Davidson, L. Kangaloo, and F.W. Alt. 1998. Late embryonic lethality and impaired V(D)J recombination in mice lacking DNA ligase IV. Nature 396: 173-177.

Fried, L.M., C. Koumenis, S.R. Peterson, S.L. Green, P. Vanzijl, J. Allalunisturner, D.J. Chen, R. Fishel, A.J. Giaccia, J.M. Brown, and C.U. Kirchgessner. 1996. The DNA damage response in DNA-dependent protein kinase-deficient SCID mouse cells: Replication protein A hyperphosphorylation and p53 induction. Proc. Natl. Acad. Sci. 93: 13825-13830.

Fukumura, R., R. Araki, A. Fujimori, M. Mori, T. Saito, F. Watanabe, M. Sarashi, H. Itsukaichi, K. EguchiKasai, K. Sato, K. Tatsumi, and M. Abe. 1998. Murine cell line SX9 bearing a mutation in the DNA pkcs gene exhibits aberrant $\mathrm{V}(\mathrm{D}) \mathrm{J}$ recombination not only in the coding joint but also in the signal joint. J. Biol. Chem. 273: 13058-13064.

Fulop, G.M. and R.A. Phillips. 1990. The SCID mutation in mice causes a general defect in DNA repair. Nature 347:
479-482.

Furuse, M., Y. Nagase, H. Tsubouchi, K. MurakamiMurofushi, T. Shibata, and K. Ohta. 1998. Distinct roles of two separable in vitro activities of yeast Mre11 in mitotic and meiotic recombination. EMBO J. 17: 6412-6425.

Gao, Y., J. Chaudhuri, C. Zhu, L. Davidson, D.T. Weaver, and F.W. Alt. 1998. A targeted DNA-PKcs-null mutation reveals DNA-PK-independent functions for $\mathrm{Ku}$ in $\mathrm{V}(\mathrm{D}) \mathrm{J}$ recombination. Immunity 9: 367-376.

Getts, R.C. and T.D. Stamato. 1994. Absence of a Ku-like DNA end binding activity in the xrs double-strand DNA repairdeficient mutant. J. Biol. Chem. 269: 15981-15984.

Giffin, W., H. Torrance, D.J. Rodda, G.G. Prefontaine, L. Pope, and R.J.G. Hache. 1996. Sequence-specific DNA binding by $\mathrm{Ku}$ autoantigen and its effects on transcription. Nature 380: $265-268$.

Gottlieb, T.M. and S.P. Jackson. 1993. The DNA-dependent protein kinase requirement for DNA ends and association with $\mathrm{Ku}$ antigen. Cell 72: 131-142.

Grant, P.A., D. Schieltz, M.G. PrayGrant, D.J. Steger, J.C. Reese, J.R. Yates, and J.L. Workman. 1998. A subset of TAF(II)s are integral components of the SAGA complex required for nucleosome acetylation and transcriptional stimulation. Cell 94: 45-53.

Gravel, S., M. Larrivee, P. Labrecque, and R.J. Wellinger. 1998. Yeast $\mathrm{Ku}$ as a regulator of chromosomal DNA end structure. Science 280: 741-744.

Grawunder, U., N. Finnie, S.P. Jackson, B. Riwar, and R. Jessberger. 1996. Expression of DNA-dependent protein kinase holoenzyme upon induction of lymphocyte differentiation and V(D)J recombination. Eur. J. Biochem. 241: 931-940.

Grawunder, U., M. Wilm, X.T. Wu, P. Kulesza, T.E. Wilson, M. Mann, and M.R. Lieber. 1997. Activity of DNA ligase IV stimulated by complex formation with XRCC4 protein in mammalian cells. Nature 388: 492-495.

Grawunder, U., D. Zimmer, S. Fugmann, K. Schwarz, and M.R. Lieber. 1998. DNA ligase IV is essential for V(D)J recombination and DNA double-strand break repair in human precursor lymphocytes. Mol. Cell 2: 477-484.

Greenwell, P.W., S.L. Kronmal, S.E. Porter, J. Gassenhuber, B. Obermaier, and T.D. Petes. 1995. Tell, a gene involved in controlling telomere length in Saccharomyces cerevisiae, is homologous to the human ataxia telangiectasia gene. Cell 82: 823-829.

Griffith, A.J., P.R. Blier, T. Mimori, and J.A. Hardin. 1992. Ku polypeptides synthesized in vitro assemble into complexes which recognize ends of double-stranded DNA. J. Biol. Chem. 267: 331-338.

Grunstein, M. 1997. Molecular model for telomeric heterochromatin in yeast. Curr. Opin. Cell Biol. 9: 383-387.

Gu, X.Y., R.A.O. Bennett, and L.F. Povirk. 1996. End joining of free radical mediated DNA double-strand breaks in vitro is blocked by the kinase inhibitor wortmannin at a step preceeding removal of damaged $3^{\prime}$ termini. I. Biol. Chem. 271: 19660-19663.

Gu, X.Y., M.A. Weinfeld, and L.F. Povirk. 1998. Implication of DNA-dependent protein kinase in an early, essential, local phosphorylation event during end joining of DNA doublestrand breaks in vitro. Biochemistry 37: 9827-9835.

Gu, Y.S., S.F. Jin, Y.J. Gao, D.T. Weaver, and F.W. Alt. 1997a. Ku70 deficient embryonic stem cells have increased ionizing radiosensitivity, defective DNA end binding activity, and inability to support V(D)J recombination. Proc. Natl. Acad. Sci. 94: 8076-8081.

Gu, Y.S., K.J. Seidl, G.A. Rathbun, C.M. Zhu, J.P. Manis, N vanderStoep, L. Davidson, H.L. Cheng, J.M. Sekiguchi, K. 
Frank, P. StanhopeBaker, M.S. Schlissel, D.B. Roth, and F.W. Alt. 1997b. Growth retardation and leaky SCID phenotype of Ku70 deficient mice. Immunity 7: 653-665.

Guidos, C.J., C.J. Williams, I. Grandal, G. Knowles, M.T.F. Huang, and J.S. Danska. 1996. $V(D) J$ recombination activates a p53-dependent DNA damage checkpoint in SCID lymphocyte precursors. Genes \& Dev. 10: 2038-2054.

Hammarsten, O. and G. Chu. 1998. DNA-dependent protein kinase: DNA binding and activation in the absence of $\mathrm{Ku}$. Proc. Natl. Acad. Sci. 95: 525-530.

Han, Z.Y., N. Malik, T. Carter, W.H. Reeves, J.H. Wyche, and E.A. Hendrickson. 1996. DNA-dependent protein kinase is a target for a Cpp32 like apoptotic protease. J. Biol. Chem. 271: 25035-25040.

Han, J.O., S.B. Steen, and D.B. Roth. 1997. Ku86 is not required for protection of signal ends or for formation of nonstandard V(D)J recombination products. Mol. Cell. Biol. 17: 22262234.

Hari, K.L., A. Santerre, J.J. Sekelsky, K.S. McKim, J.B. Boyd, and R.S. Hawley. 1995. The Mei 41 gene of Drosophila melanogaster is a structural and functional homolog of the human ataxia telangiectasia gene. Cell 82: 815-821.

Harriman, W., H. Volk, N. Defranoux, and M. Wabl. 1993. Immunoglobulin class switch recombination. Annu. Rev. Immunol. 11: 361-384.

Hartley, K.O., D. Gell, G.C.M. Smith, H. Zhang, N. Divecha, M.A. Connelly, A. Admon, S.P. Lees-Miller, C.W. Anderson, and S.P. Jackson. 1995. DNA-dependent protein kinase catalytic subunit a relative of phosphatidylinositol 3-kinase and the ataxia telangiectasia gene product. Cell 82: 849-856.

Haupt, Y., R. Maya, A. Kazaz, and M. Oren. 1997. Mdm2 promotes the rapid degradation of p53. Nature 387: 296-299.

Heitman, J., N.R. Movva, and M.N. Hall. 1991. Targets for cellcycle arrest by the immunosuppressant rapamycin in yeast. Science 253: 905-909.

Helliwell, S.B., P. Wagner, J. Kunz, M. Deuter-Reinhard, R. Henriquez, and M.N. Hall. 1994. Tor1 and Tor2 are structurally and functionally similar but not identical phosphatidylinositol kinase homologs in yeast. Mol. Biol. Cell 5: 105-118.

Hendrickson, E.A., X.Q. Qin, E.A. Bump, D.G. Schatz, M. Oettinger, and D.T. Weaver. 1991. A link between double-strand break related repair and V(D)J recombination in the SCID mutation. Proc. Nat1. Acad. Sci. 88: 4061-4065.

Herrmann, G., T. Lindahl, and P. Schar. 1998. Saccharomyces cerevisiae LIF1: A function involved in DNA double-strand break repair related to mammalian XRCC4. EMBO I. 17: 4188-4198.

Hosoi, Y., H. Miyachi, Y. Matsumoto, H. Ikehata, J. Komura, K. Ishii., H.J. Zhao, M. Yoshida, Y. Takai, S. Yamada, N. Suzuki, and T. Ono. 1998. A phosphatidylinositol 3-kinase inhibitor wortmannin induces radioresistant DNA synthesis and sensitizes cells to bleomycin and ionizing radiation. Intl. J. Cancer 78: 642-647.

Huang, L.C., K.C. Clarkin, and G.M. Wahl. 1996. p53-dependent cell cycle arrests are preserved in DNA-activated protein kinase deficient mouse fibroblasts. Cancer Res. 56: $2940-2944$.

Huang, J.R., A. Nueda, S. Yoo, and W.S. Dynan. 1997. Heat shock transcription factor 1 binds selectively in vitro to $\mathrm{Ku}$ protein and the catalytic subunit of the DNA-dependent protein kinase. J. Biol Chem. 272: 26009-26016.

Izzard, R.A., S.P. Jackson, and G.C.M. Smith. 1999. Competitive and noncompetitive inhibition of the DNA-dependent protein kinase. Cancer Res. (in press).

Jackson, S.P. 1996. DNA damage detection by DNA-dependent protein kinase and related enzymes. Cancer Surv. 28: 261-
279

Jackson, S.P., J.J. Macdonald, S. Lees-Miller, and R. Tjian. 1990. GC box binding induces phosphorylation of Sp1 by a DNAdependent protein kinase. Cell 63: 155-165.

Jhappan, C., H.C. Morse, R.D. Fleischmann, M.M. Gottesman, and G. Merlino. 1997. DNA PKcs: A T cell tumour suppressor encoded at the mouse SCID locus. Nat. Genet. 17: 483486.

Jimenez, G., J. Yucel, R. Rowley, and S. Subramani. 1992. The Rad3+ gene of Schizosaccharomyces pombe is involved in multiple checkpoint functions and in DNA repair. Proc. Natl. Acad. Sci. 89: 4952-4956.

Jin, S.F. and D.T. Weaver. 1997. Double-strand break repair by $\mathrm{Ku} 70$ requires heterodimerization with $\mathrm{Ku} 80$ and DNA binding functions. EMBO J. 16: 6874-6885.

Jin, S.F., S. Inoue, and D.T. Weaver. 1998. Differential etoposide sensitivity of cells deficient in the Ku and DNA PKcs components of the DNA-dependent protein kinase. Carcinogenesis 19: 965-971.

Jin, S.F., S. Kharbanda, B. Mayer, D. Kufe, and D.T. Weaver 1997. Binding of Ku and c-Abl at the kinase homology region of DNA-dependent protein kinase catalytic subunit. J. Biol. Chem. 272: 24763-24766.

Jongmans, W., M. Vuillaume, K. Chrzanowska, D. Smeets, K. Sperling, and J. Hall. 1997. Nijmegen breakage syndrome cells fail to induce the p53-mediated DNA damage response following exposure to ionizing radiation. Mol. Cell. Biol. 17: 5016-5022.

Kanaar, R., J.H.J. Hoeijmakers, and D.C. van Gent. 1998. Molecular mechanisms of DNA double-strand break repair. Trends Cell Biol. 8: 483-489.

Kastan, M.B. 1992 A mammalian cell cycle checkpoint pathway utilizing p53 and Gadd45 is defective in ataxia telangiectasia. Cell 71: 587-597.

Kato, R. and H. Ogawa. 1994. An essential gene, Esrl, is required for mitotic cell growth, DNA repair and meiotic recombination in Saccharomyces cerevisiae. Nucleic Acids Res. 22: 3104-3112.

Khanna, K.K., K.E. Keating, S. Kozlov, S. Scott, M. Gatei, K. Hobson, Y. Taya, B. Gabrielli, D. Chan, S.P. Lees-Miller, and M.F. Lavin. 1998. ATM associates with and phosphorylates p53: Mapping the region of interaction. Nat. Genet. 20: 398 400.

Kharbanda, S., P. Pandey, S.F. Jin, S. Inoue, A. Bharti, Z.M. Yuan, R. Weichselbaum, D. Weaver, and D. Kufe. 1997. Functional interaction between DNA-PK and c Abl in response to DNA damage. Nature 386: 732-735.

Kirchgessner, C.U., C.K. Patil, J.W. Evans, C.A. Cuomo, L.M. Fried, T. Carter, M.A. Oettinger, and J.M. Brown. 1995. DNA-dependent kinase (p350) as a candidate gene for the murine SCID defect. Science 267: 1178-1183.

Ko, L.C. and C. Prives. 1996. p53: Puzzle and paradigm. Genes \& Dev. 10: 1054-1072

Korte, C.C. and L.S. Yasui. 1993. Morphological characterization of the radiation sensitive cell line, xrs 5. Scanning Microsc. 7: 943-951.

Kubbutat, M.H.G., S.N. Jones, and K.H. Vousden. 1997. Regulation of p53 stability by Mdm2. Nature 387: 299-303.

Kuhn, A., T.M. Gottlieb, S.P. Jackson, and I. Grummt. 1995. DNA-dependent protein kinase a potent inhibitor of transcription by RNA polymerase I. Genes \& Dev. 9: 193-203.

Kumar, S., P. Pandey, A. Bharti, S.F. Jin, R. Weichselbaum, D. Weavers, D. Kufe, and S. Kharbanda. 1998. Regulation of DNA-dependent protein kinase by the Lyn tyrosine kinase. J. Biol. Chem. 273: 25654-25658.

Kunz, J., R. Henriquez, V. Schneider, M. Deuterreinhard, N.R. 
Movva, and M.N. Hall. 1993. Target of rapamycin, TOR2, is an essential phosphatidylinositol kinase homolog required for $\mathrm{G}(1)$ progression. Cell 73: 585-596.

Labhart, P. 1995. DNA-dependent protein kinase specifically represses promoter directed transcription initiation by RNA polymerase I. Proc. Nat1. Acad. Sci. 92: 2934-2938.

-1997. mRNA encoding the catalytic subunit of DNAdependent protein kinase is widely expressed in Xenopus cells. Gene 203: 235-240.

Laroche, T., S.G. Martin, M. Gotta, H.C. Gorham, F.E. Pryde, E.J. Louis, and S.M. Gasser. 1998. Mutation of yeast Ku genes disrupts the subnuclear organization of telomeres. Curr. Biol. 8: 653-656.

Lavin, M.F. and Y. Shiloh. 1997. The genetic defect in ataxiatelangiectasia. Annu. Rev. Immunol. 15: 177-202.

Leber, R., T.W. Wise, R. Mizuta, and K. Meek. 1998. The XRCC4 gene product is a target for and interacts with the DNA-dependent protein kinase. J. Biol. Chem. 273: 17941801.

Lee, S.E., R.A. Mitchell, A. Cheng, and E.A. Hendrickson. 1997. Evidence for DNA-PK-dependent and independent DNA double-strand break repair pathways in mammalian cells as a function of the cell cycle. Mol. Cell. Biol. 17: 1425-1433.

Lees-Miller, S.P., Y.R. Chen, and C.W. Anderson. 1990. Human cells contain a DNA-activated protein kinase that phosphorylates simian virus $40 \mathrm{~T}$-antigen, mouse p53, and the human Ku autoantigen. Mol. Cell. Biol. 10: 6472-6481.

Lees-Miller, S.P., K. Sakaguchi, S.J. Ullrich, E. Appella, and C.W. Anderson. 1992. Human DNA-activated protein kinase phosphorylates serine 15 and serine 37 in the amino terminal transactivation domain of human p53. Mol. Cell. Biol. 12: 5041-5049.

Lees-Miller, S.P., R. Godbout, D.W. Chan, M. Weinfeld, R.S. Day, G.M. Barron, and J. Allalunisturner. 1995. Absence of p350 subunit of DNA-activated protein kinase from a radiosensitive human cell line. Science 267: 1183-1185.

Lees-Miller, S.P., M.C. Long, M.A. Kilvert, V. Lam, S.A. Rice, and C.A. Spencer. 1996. Attenuation of DNA-dependent protein kinase activity and its catalytic subunit by the herpes simplex virus type 1 transactivator ICP0. J. Virol. 70: 74717477.

LeRomancer, M., S.C. Cosulich, S.P. Jackson, and P.R. Clarke. 1996. Cleavage and inactivation of DNA-dependent protein kinase catalytic subunit during apoptosis in Xenopus egg extracts. J. Cell Sci. 109: 3121-3127.

Leuther, K.K., O. Hammarstan, R.D. Kornberg, and G. Chu. 1999. Structure of DNA-dependent protein kinase: Implications for its regulation by DNA. EMBO J.18:1114-1123.

Li, G.C., H.H. Ouyang, X.L. Li, H. Nagasawa, J.B. Little, D.J. Chen, C.C. Ling, Z. Fuks, and C. CordonCardo. 1998. Ku70: A candidate tumor suppressor gene for murine $\mathrm{T}$ cell lymphoma. Mol. Cell 2: 1-8.

Li, Z.Y., T. Otevrel, Y.J. Gao, H.L. Cheng, B. Seed, T.D. Stamato, G.E. Taccioli, and F.W. Alt. 1995. The XRCC4 gene encodes a novel protein involved in DNA double-strand break repair and V(D)J recombination. Cell 83: 1079-1089.

Liang, F. and M. Jasin. 1996. Ku80 deficient cells exhibit excess degradation of extrachromosomal DNA. I. Biol. Chem. 271: 14405-14411.

Lieber, M.R., J.E. Hesse, S. Lewis, G.C. Bosma, N. Rosenberg, K. Mizuuchi, M.J. Bosma, and M. Gellert. 1988. The defect in murine severe combined immune deficiency joining of signal sequences but not coding segments in $\mathrm{V}(\mathrm{D}) \mathrm{J}$ recombination. Cell 55: 7-16.

Mages, G.J., H.M. Feldmann, and E.L. Winnacker. 1996. Involvement of the Saccharomyces cerevisiae hdf1 gene in
DNA double-strand break repair and recombination. J. Biol. Chem. 271: 7910-7915.

Manis, J.P., Y.S. Gu, R. Lansford, E. Sonoda, R. Ferrini, L. Davidson, K. Rajewsky, and F.W. Alt. 1998. Ku70 is required for late B cell development and immunoglobulin heavy chain class switching. J. Exp. Med. 187: 2081-2089.

Maser, R.S., K.J. Monsen, B.E. Nelms, and J.H.J. Petrini. 1997. hMre11 and hRad50 nuclear foci are induced during the normal cellular response to DNA double-strand breaks. Mol. Cell. Biol. 17: 6087-6096.

Matsuura, K., T. Balmukhanov, H. Tauchi, C. Weemaes, D. Smeets, K. Chrzanowska, S. Endou, S. Matsuura, and K. Komatsu. 1998a. Radiation induction of p53 in cells from Nijmegen breakage syndrome is defective but not similar to ataxia telangiectasia. Biochem. Biophys. Res. Commun. 242: 602-607.

Matsuura, S., H. Tauchi, A. Nakamura, N. Kondo, S. Sakamoto, S. Endo, D. Smeets, B. Solder, B.H. Belohradsky, V.M.D. Kaloustian, M. Oshimura, M. Isomura, Y. Nakamura, and K. Komatsu. 1998b. Positional cloning of the gene for Nijmegen breakage syndrome. Nat. Genet. 19: 179-181.

Mayo, L.D., J.J. Turchi, and S.J. Berberich. 1997. Mdm-2 phosphorylation by DNA-dependent protein kinase prevens interaction with p53. Cancer Res. 57: 5013-5016.

McBlane, J.F., D.C. Vangent, D.A. Ramsden, C. Romeo, C.A. Cuomo, M. Gellert, and M.A. Oettinger. 1995. Cleavage at a $\mathrm{V}(\mathrm{D}) \mathrm{J}$ recombination signal requires only RAG1 and RAG2 proteins and occurs in two steps. Cell 83: 387-395.

McMahon, S.B., H.A. VanBuskirk, K.A. Dugan, T.D. Copeland, and M.D. Cole. 1998. The novel ATM-related protein TRRAP is an essential cofactor for the c Myc and E2F oncoproteins. Cell 94: 363-374.

Milne, G.T., S. Jin, K.B. Shannon, and D.T. Weaver. 1996. Mutations in two Ku homologs define a DNA end-joining repair pathway in Saccharomyces cerevisiae. Mol. Cell. Biol. 16: 4189-4198.

Mimori, T. and J.A. Hardin. 1986. Mechanism of interaction between Ku protein and DNA. J. Biol. Chem. 261: 375-379.

Mimori, T., M. Akizuki, H. Yamagata, S. Inada, S. Yoshida, and M. Homma. 1981. Characterization of a high molecular weight acidic nuclear protein recognized by autoantibodies in sera from patients with polymyositis scleroderma overlap. J. Clin. Invest. 68: 611-620.

Moreau, S., J.R. Ferguson, and L.S. Symington. 1999. The nuclease activity of Mre11 is required for meiosis but not for mating type switching, end joining, or telomere maintenance. Mol. Cell. Biol. 19: 556-566.

Morrison, C., G.C.M. Smith, L. Stingl, S.P. Jackson, E.F. Wagner, and Z.Q. Wang. 1997. Genetic interaction between PARP and DNA-PK in V(D)J recombination and tumorigenesis. Nat. Genet. 17: 479-482.

Morrow, D.M., M. Morrow, D.A. Tagle, Y. Shiloh, F.S. Collins, and P. Hieter. 1995. Tel1, a Saccharomyces cerevisiae homolog of the human gene mutated in ataxia telangiectasia, is functionally related to the yeast checkpoint gene Mec1. Cell 82: $831-840$.

Myung, K., D.M. He, S.E. Lee, and E.A. Hendrickson. 1997. KARP 1: A novel leucine zipper protein expressed from the $\mathrm{Ku} 86$ autoantigen locus is implicated in the control of DNAdependent protein kinase activity. EMBO J. 16: 3172- 3184.

Myung, K., C. Braastad, D.M. He, and E.A. Hendrickson. 1998. KARP 1 is induced by DNA damage in a p53 and ataxia telangiectasia mutated dependent fashion. Proc. Natl. Acad. Sci. 95: 7664-7669.

Nacht, M., A. Strasser, Y.R. Chan, A.W. Harris, M. Schlissel, R. Bronson, and T. Jacks. 1996. Mutations in the p53 and SCID 
genes cooperate in tumorigenesis. Genes \& Dev. 10: 2055 2066.

Naito, T., A. Matsuura, and F. Ishikawa. 1998. Circular chromosome formation in a fission yeast mutant defective in two ATM homologs. Nat. Genet. 20: 203-206.

Natarajan, K., B.M. Jackson, E. Rhee, and A.G. Hinnebusch. 1998. yTAF(II)61 has a general role in RNA polymerase II transcription and is required by GCN4p to recruit the SAGA coactivator complex. Mol. Cell 2: 683-692.

Nelms, B.E., R.S. Maser, J.F. MacKay, M.G. Lagally, and J.H.J. Petrini. 1998. In situ visualization of DNA double-strand break repair in human fibroblasts. Science 280: 590-592.

Nugent, C.I., G. Bosco, L.O. Ross, S.K. Evans, A.P. Salinger, J.K. Moore, J.E. Haber, and V. Lundblad. 1998. Telomere maintenance is dependent on activities required for end repair of double-strand breaks. Curr. Biol. 8: 657-660.

Nussenzweig, A., C.H. Chen, V.D. Soares, M. Sanchez, K. Sokol, M.C. Nussenzweig, and G.C. Li. 1996. Requirement for $\mathrm{Ku} 80$ in growth and immunoglobulin V(D)J recombination. Nature 382: 551-555.

Nussenzweig, A., K. Sokol, P. Burgman, L.G. Li, and G.C. Li. 1997. Hypersensitivity of Ku80 deficient cell lines and mice to DNA damage: The effects of ionizing radiation on growth, survival, and development. Proc. Natl. Acad. Sci. 94: 1358813593.

Ochem, A.E., D. Skopac, M. Costa, T. Rabilloud, L. Vuillard, A. Simoncsits, M. Giacca, and A. Falaschi. 1997. Functional properties of the separate subunits of human DNA helicase II Ku autoantigen. J. Biol. Chem. 272: 29919-29926.

Ohtsuki, K., E. Yamada, M. Nakamura, and N. Ishida. 1980. Mouse spleen cell nuclear protein kinases and the stimulating effect of dsDNA on NHP phosphorylation by cyclic AMP-independent protein kinase in vitro. J. Biochem. 87: 35-45.

Ono, M., P.W. Tucker, and J.D. Capra. 1994. Production and characterization of recombinant human Ku antigen. Nucleic Acids Res. 22: 3918-3924.

Osipovich, O., S.K. Durum, and K. Muegge. 1997. Defining the minimal domain of Ku80 for interaction with Ku70. J. Biol. Chem. 272: 27259-27265.

Ouyang, H., A. Nussenzweig, A. Kurimasa, V.D. Soares, X.L. Li, C. Cordon-Cardo, W.H. Li, N. Cheong, M. Nussenzweig, G. Iliakis, D.J. Chen and G.C. Li. 1997. Ku70 is required for DNA repair but not for $\mathrm{T}$ cell antigen receptor gene recombination in vivo. J. Exp. Med. 186: 921-929.

Paillard, S. and F. Strauss. 1991. Analysis of the mechanism of interaction of simian $\mathrm{Ku}$ protein with DNA. Nucleic Acids Res. 19: 5619-5624.

Parkinson, J., S.P. Lees-Miller, and R.D. Everett. 1999. Herpes simplex virus type 1 immediate-early protein Vmw110 induces the proteosome-dependent degradation of the catalytic subunit of DNA-dependent protein kinase. J. Virol. 73: 650657.

Paull, T.T. and M. Gellert. 1998. The 3'- to- 5' exonuclease activity of Mre11 facilitates repair of DNA double-strand breaks. Mol. Cell 1: 969-979.

Pergola, F., M.Z. Zdzienicka, and M.R. Lieber. 1993. V(D)J recombination in mammalian cell mutants defective in DNA double-strand break repair. Mol. Cell. Biol. 13: 3464-3471.

Peterson, S.R., S.A. Jesch, T.N. Chamberlin, A. Dvir, S.K. Rabindran, C. Wu, and W.S. Dynan. 1995a. Stimulation of the DNA-dependent protein kinase by RNA Polymerase II transcriptional activator proteins. I. Biol. Chem. 270: 14491454.

Peterson, S.R., A. Kurimasa, M. Oshimura, W.S. Dynan, E.M. Bradbury, and D.J. Chen. 1995b. Loss of the catalytic subunit of the DNA-dependent protein kinase in DNA double-strand break repair mutant mammalian cells. Proc. Natl. Acad. Sci. 92: $3171-3174$.

Peterson, S.R., M. Stackhouse, M.J. Waltman, F.Q. Chen, K. Sato, and D.J. Chen. 1997. Characterization of two DNA double-stranded break repair-deficient cell lines that express inactive DNA-dependent protein kinase catalytic subunits. J. Biol. Chem. 272: 10227-10231.

Polotnianka, R.M., J. Li, and A.J. Lustig. 1998. The yeast Ku heterodimer is essential for protection of the telomere against nucleolytic and recombinational activities. Curr. Biol. 8: 831-834.

Poltoratsky, V.P., X.Y. Shi, J.D. York, M.R. Lieber, and T.H. Carter. 1995. Human DNA-activated protein kinase (DNA$\mathrm{PK}$ ) is homologous to phosphatidylinositol kinases. J. Immunol. 155: 4529-4533.

Porter, S.E., P.W. Greenwell, K.B. Ritchie, and T.D. Petes. 1996. The DNA binding protein Hdflp (a putative Ku homolog) is required for maintaining normal telomere length in Saccharomyces cerevisiae. Nucleic Acids Res. 24: 582-585.

Price, B.D. and M.B. Youmell. 1996. The phosphatidylinositol 3-kinase inhibitor wortmannin sensitizes murine fibroblasts and human tumor cells to radiation and blocks induction of p53 following DNA damage. Cancer Res. 56: 246-250.

Priestley, A., H.J. Beamish, D. Gell, A.G. Amatucci, M.C. MuhlmannDiaz, B.K. Singleton, G.C.M. Smith, T. Blunt, L.C. Schalkwyk, J.S. Bedford, S.P. Jackson, P.A. Jeggo, and G.E. Taccioli. 1998. Molecular and biochemical characterisation of DNA-dependent protein kinase defective rodent mutant irs 20. Nucleic Acids Res. 26: 1965-1973.

Ramos, W., G. Liu, C.N. Giroux, and A.E. Tomkinson. 1998. Biochemical and genetic characterization of the DNA ligase encoded by Saccharomyces cerevisiae open reading frame YOROO5c, a homolg of mammalian DNA ligase IV. Nucleic Acids Res. 26: 5676-5683.

Ramsden, D.A. and M. Gellert. 1998. Ku protein stimulates DNA end joining by mammalian DNA ligases: A direct role for $\mathrm{Ku}$ in repair of DNA double-strand breaks. $E M B O J$. 17: 609-614.

Ramsden, D.A., D.C. van Gent, and M. Gellert. 1997. Specificity in $\mathrm{V}(\mathrm{D}) \mathrm{J}$ recombination: New lessons from biochemistry and genetics. Curr. Opin. Immunol. 9: 114-120.

Rathmell, W.K. and G. Chu. 1994. A DNA end binding factor involved in double-strand break repair and V(D)J recombination. Mol. Cell. Biol. 14: 4741-4748.

Rathmell, W.K., W.K. Kaufmann, J.C. Hurt, L.L. Byrd, and G. Chu. 1997. DNA-dependent protein kinase is not required for accumulation of p53 or cell cycle arrest after DNA damage. Cancer Res. 57: 68-74.

Rolink, A., F. Melchers, and J. Andersson. 1996. The SCID but not the RAG-2 gene product is required for $S \mu-S \in$ heavy chain class switching. Immunity 5: 319-330.

Rosenzweig, K.E., M.B. Youmell, S.T. Palayoor, and B.D. Price. 1997. Radiosensitization of human tumor cells by the phosphatidylinositol 3-kinase inhibitors Wortmannin and LY294002 correlates with inhibition of DNA-dependent protein kinase and prolonged G(2) M delay. Clin. Cancer Res. 3: 1149-1156.

Rotman, G. and Y. Shiloh. 1998. ATM: From gene to function. Hum. Mol. Genet. 7: 1555-1563.

Ruscetti, T., B.E. Lehnert, J. Halbrook, H. LeTrong, M.F. Hoekstra, D.J. Chen, and S.R. Peterson. 1998. Stimulation of the DNA-dependent protein kinase by poly(ADP ribose) polymerase. J. Biol. Chem. 273: 14461-14467.

Sabatini, D.M., H. Erdjument-Bromage, M. Liu, P. Tempst, and S.H. Snyder. 1994. RAFT1- A mammalian protein that binds 
to FKBP12 in a rapamycin-dependent fashion and is homologous to yeast Tors. Cell 78: 35-43.

Saleh, A., D. Schieltz, N. Ting, S.B. McMahon, D.W. Litchfield, J.R. Yates, S.P. Lees-Miller, M.D. Cole, and C.J. Brandl. 1998. Tralp is a component of the yeast Ada center dot Spt transcriptional regulatory complexes. J. Biol. Chem. 273: 2655926565.

Schar, P., G. Herrmann, G. Daly, and T. Lindahl. 1997. A newly identified DNA ligase of Saccharomyces cerevisiae involved in RAD52-independent repair of DNA double-strand breaks. Genes \& Dev. 11: 1912-1924.

Seaton, B.L., J. Yucel, P. Sunnerhagen, and S. Subramani. 1992. Isolation and characterization of the Schizosaccharomyces pombe Rad3 gene, involved in the DNA damage and DNA synthesis checkpoints. Gene 119: 83-89.

Shieh, S.Y., M. Ikeda, Y. Taya, and C. Prives. 1997. DNA damage-induced phosphorylation of p53 alleviates inhibition by MDM2. Cell 91: 325-334.

Shin, E.K., L.E. Perryman, and K. Meek. 1997. A kinase negative mutation of DNA-PKcs in equine SCID results in defective coding and signal joint formation. J. Immunol. 158: 3565 3569.

Shore, D. 1998. Telomeres-unsticky ends. Science 281: 18181819.

Siede, W., A.A. Friedl, I. Dianova, F. Eckardt-Schupp, and E.C. Friedberg. 1996. The Saccharomyces cerevisiae Ku autoantigen homolog affects radiosensitivity only in the absence of homologous recombination. Genetics 142: 91-102.

Singleton, B.K., A. Priestley, H. Steingrimsdottir, D. Gell, T. Blunt, S.P. Jackson, A.R. Lehmann, and P.A. Jeggo. 1997. Molecular and biochemical characterization of xrs mutants defective in Ku80. Mol. Cell. Biol. 17: 1264-1273.

Smider, V., W.K. Rathmell, M.R. Lieber, and G. Chu. 1994. Restoration of X-ray resistance and V(D)J recombination in mutant cells by Ku cDNA. Science 266: 288-291.

Smider, V., W.K. Rathmell, G. Brown, S. Lewis, and G. Chu. 1998. Failure of hairpin ended and nicked DNA to activate DNA-dependent protein kinase: Implications for $\mathrm{V}(\mathrm{D}) \mathrm{J}$ recombination. Mol. Cell. Biol. 18: 6853-6858.

Smith, G.C.M., N. Divecha, N.D. Lakin, and S.P. Jackson. 1999. DNA-dependent protein kinase and related proteins. Biochem. Soc. Symp. 64: 91-104.

Song, Q., S.P. Lees-Miller, S. Kumar, Z. Zhang, D.W. Chan, G.C.M. Smith, S.P. Jackson, E.S. Alnemri, G. Litwack, K.K. Khanna, and M.F. Lavin. 1996. DNA-dependent protein kinase catalytic subunit: A target for an ICE-like protease in apoptosis. EMBO I. 15: 3238-3246.

Suwa, A., M. Hirakata, Y. Takeda, S.A. Jesch, T. Mimori, and J.A. Hardin. 1994. DNA-dependent protein kinase (Ku protein p350 complex) assembles on double-stranded DNA. Proc. Nat1. Acad. Sci. 91: 6904-6908.

Taccioli, G.E., G. Rathbun, E. Oltz, T. Stamato, P.A. Jeggo, and F.W. Alt. 1993. Impairment of $\mathrm{V}(\mathrm{D}) \mathrm{J}$ recombination in double-strand break repair mutants. Science 260: 207-210.

Taccioli, G.E., T.M. Gottlieb, T. Blunt, A. Priestley, J. Demengeot, R. Mizuta, A.R. Lehmann, F.W. Alt, S.P. Jackson, and P.A. Jeggo. 1994. Ku80 product of the Xrcc5 gene and its role in DNA repair and V(D)J recombination. Science 265: 1442 1445.

Taccioli, G.E., A.G. Amatucci, H.J. Beamish, D. Gell, X.H. Xiang, M.I.T. Arzayus, A. Priestley, S.P. Jackson, A.M. Rothstein, P.A. Jeggo, and V.L.M. Herrera. 1998. Targeted disruption of the catalytic subunit of the DNA-PK gene in mice confers severe combined immunodeficiency and radiosensitivity. Immunity 9: 355-366.

Take, Y., M. Kumano, Y. Hamano, H. Fukatsu, H. Teraoka, S.
Nishimura, and A. Okuyama. 1995. OK 1035, a selective inhibitor of DNA-dependent protein kinase. Biochem. Biophys. Res. Commun. 215: 41-47.

Take, Y., M. Kumano, H. Teraoka, S. Nishimura, and A. Okuyama. 1996. DNA-dependent protein kinase inhibitor (OK 1035) suppresses p21 expression in Hct116 cells containing wild-type p53 induced by adriamycin. Biochem. Biophys. Res. Commun. 221: 207-212.

Teo, S.H. and S.P. Jackson. 1997. Identification of Saccharomyces cerevisiae DNA ligase IV: Involvement in DNA doublestrand break repair. EMBO J. 16: 4788-4795.

Thompson, L.H. and P.A. Jeggo. 1995. Nomenclature of human genes involved in ionizing radiation sensitivity. Mut. Res. DNA Rep. 337: 131-134.

Tibbets, R.S., K.M. Brumbaugh, J.M. Williams, J.N. Sarkaria, W.A. Cliby, S.-Y. Shieh, Y. Taya, C. Prives, and R.T. Abraham. 1999. A role for ATR in the DNA damage-induced phosphorylation of p53. Genes \& Dev. 13: 152-157.

Toker, A. and L.C. Cantley. 1997. Signaling through the lipid products of phosphoinositide-3-OH kinase. Nature 387: 673-676.

Trujillo, K.M., S.S.F. Yuan, E. Lee, and P. Sung. 1998. Nuclease activities in a complex of human recombination and DNA repair factors Rad50, Mre11, and p95. J. Biol. Chem. 273: 21447-21450.

Tsukamoto, Y., J. Kato, and H. Ikeda. 1997. Silencing factors participate in DNA repair and recombination in Saccharomyces cerevisiae. Nature 388: 900-903.

Tuteja, N., R. Tuteja, A. Ochem, P. Taneja, N.W. Huang, A. Simoncsits, S. Susic, K. Rahman, L. Marusic, J.Q. Chen, J.W. Zhang, S.G. Wang, S. Pongor, and A. Falaschi. 1994. Human DNA helicase II a novel DNA unwinding enzyme identified as the $\mathrm{Ku}$ autoantigen. EMBO J. 13: 4991-5001.

Varon, R., C. Vissinga, M. Platzer, K.M. Cerosaletti, K.H. Chrzanowska, K. Saar, G. Beckmann, E. Seemanova, P.R. Cooper, N.J. Nowak, M. Stumm, C.M.R. Weemaes, R.A. Gatti, R.K. Wilson, M. Digweed, A. Rosenthal, K. Sperling, P. Concannon, and A. Reis. 1998. Nibrin, a novel DNA doublestrand break repair protein, is mutated in Nijmegen breakage syndrome. Cell 93: 467-476.

Walker, A.I., T. Hunt, R.J. Jackson, and C.W. Anderson. 1985. Double-stranded DNA induces the phosphorylation of several proteins including the $90,000 \mathrm{~mol} w \mathrm{w}$ heat shock protein in animal cell extracts. EMBO J. 4: 139-145.

Wang, J.S., X.W. Dong, K.J. Myung, E.A. Hendrickson, and W.H. Reeves. 1998. Identification of two domains of the p70 Ku protein mediating dimerization with $\mathrm{p} 80$ and DNA binding. J. Biol. Chem. 273: 842-848.

Watanabe, F., H. Shirakawa, M. Yoshida, K. Tsukada, and H. Teraoka. 1994. Stimulation of DNA-dependent protein kinase activity by high mobility group protein 1 and protein 2 . Biochem. Biophys. Res. Commun. 202: 736-742.

Weinert, T.A., G.L. Kiser, and L.H. Hartwell. 1994. Mitotic checkpoint genes in budding yeast and the dependence of mitosis on DNA replication and repair. Genes \& Dev. 8: 652-665.

West, R.B., M. Yaneva, and M.R. Lieber. 1998. Productive and nonproductive complexes of $\mathrm{Ku}$ and DNA-dependent protein kinase at DNA termini. Mol. Cell. Biol. 18: 5908-5920.

Wiler, R., R. Leber, B.B. Moore, L.F. Vandyk, L.E. Perryman, and K. Meek. 1995. Equine severe combined immunodeficiency a defect in $\mathrm{V}(\mathrm{D}) \mathrm{J}$ recombination and DNA-dependent protein kinase activity. Proc. Natl. Acad. Sci. 92: 11485-11489.

Wilson, T.E., U. Grawunder, and M.R. Lieber. 1997. Yeast DNA ligase IV mediates non-homologous DNA end joining. $\mathrm{Na}$ ture 388: 495-498. 
Woo, R.A., K.G. McLure, S.P. Lees-Miller, D.E. Rancourt, and P.W.K. Lee. 1998. DNA-dependent protein kinase acts upstream of p53 in response to DNA damage. Nature 394: 700704.

Wu, X.T. and M.R. Lieber. 1996. Protein-protein and proteinDNA interaction regions within the DNA end-binding protein Ku70 Ku86. Mol. Cell. Biol. 16: 5186-5193.

Wuerffel, R.A., J. Du, R.J. Thompson, and A.L. Kenter. 1997. Ig S $\gamma 3$ DNA-specific double-strand breaks are induced in mitogen-activated B cells and are implicated in switch recombination. J. Immunol. 159: 4139-4144.

Yaneva, M., T. Kowalewski, and M.R. Lieber. 1997. Interaction of DNA-dependent protein kinase with DNA and with Ku: Biochemical and atomic force microscopy studies. EMBO J. 16: 5098-5112.

Yasui, L.S., L. Lingindeck, B. Johnsonwint, T.J. Fink, and D. Molsen. 1991. Changes in the nuclear structure in the radiation sensitive CHO mutant cell, xrs 5. Radiat. Res. 127: 269-277.

Yavuzer, U., G.C.M. Smith, T. Bliss, D. Werner, and S.P. Jackson. 1998. DNA end-independent activation of DNA-PK mediated via association with the DNA-binding protein C1D. Genes \& Dev. 12: 2188-2199.

Yoo, S. and W.S. Dynan. 1998. Characterization of the RNA binding properties of $\mathrm{Ku}$ protein. Biochemistry 37: 13361343.

Yumoto, Y., H. Shirakawa, M. Yoshida, A. Suwa, F. Watanabe, and $\mathrm{H}$. Teraoka. 1998. High mobility group proteins 1 and 2 can function as DNA binding regulatory components for DNA-dependent protein kinase in vitro. J. Biol. Chem. 124: 519-527.

Zakian, V.A. 1995. ATM related genes: What do they tell us about functions of the human gene? Cell 82: 685-687.

Zdzienicka, M.Z. 1995. Mammalian mutants defective in the response to ionizing radiation-induced DNA damage. Mut. Res. DNA Rep. 336: 203-213.

Zhu, C.M., M.A. Bogue, D.S. Lim, P. Hasty, and D.B. Roth. 1996. Ku86-deficient mice exhibit severe combined immunodeficiency and defective processing of $\mathrm{V}(\mathrm{D}) \mathrm{J}$ recombination intermediates. Cell 86: 379-389. 


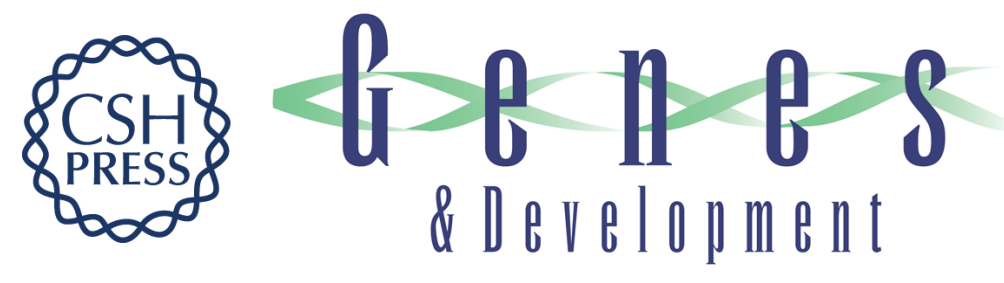

\section{The DNA-dependent protein kinase}

Graeme C.M. Smith and Stephen P. Jackson

Genes Dev. 1999, 13:

References This article cites 232 articles, 119 of which can be accessed free at: http://genesdev.cshlp.org/content/13/8/916.full.htmI\#ref-list-1

License

Email Alerting

Receive free email alerts when new articles cite this article - sign up in the box at the top Service right corner of the article or click here.

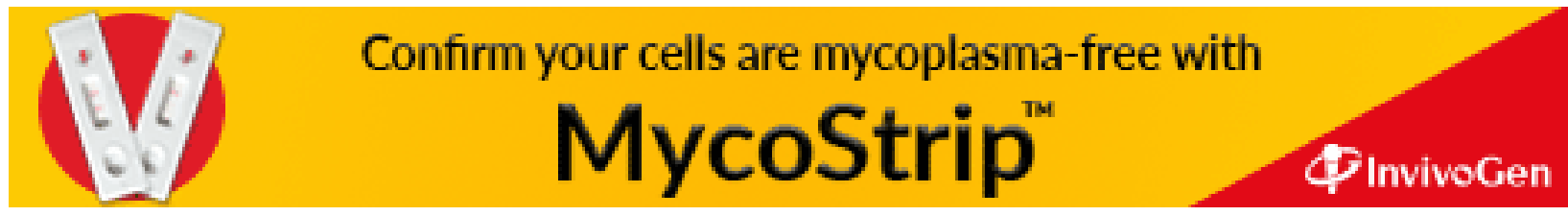

